\title{
COHESION POLICY CHALLENGES AND DISCOVERY IN 2021-2027 THE CASE OF HUNGARY
}

\author{
Pál SZABÓ ${ }^{\mathrm{a}}$, Viktória JÓZSA ${ }^{\mathrm{b}}$, Tamás GORDOS ${ }^{\mathrm{c}}$

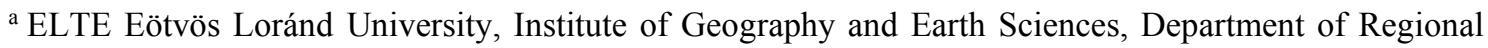 \\ Science,pal.szabo@ttk.elte.hu \\ ${ }^{\mathrm{b}}$ Nord Consult Ltd., viktoria.jozsa@gmail.com \\ ${ }^{c}$ ELTE Eötvös Loránd University, Institute of Geography and Earth Sciences, Department of Regional \\ Science, gordos.tamas@ttk.elte.hu
}

Cite this article: Szabó, P., Józsa, V., Gordos, T. (2021). Cohesion policy challenges and discovery in 20212027. The case of Hungary. Deturope, 13(2): 66-100.

\begin{abstract}
With the political agreement by the European Parliament and the Council on the Commission's proposal for 2021-2027 on the European Regional Development Fund (ERDF), the Cohesion Fund (CF) and the European Territorial Cooperation Programmes („Interreg”), and all the other instruments related to cohesion policy, we have entered the final stage of the provisions for the new EU programming period: the final approval of the legal texts (EC, 2020a).

Thus, the main objective of our study is to present the most important challenges at the Member State level (Hungary) with a bottom-up and practice-oriented perspective. Methodologically, three specific factors were identified and studied in the paper that constitute significant challenge for national level policymaking, as follows: (1) as regards the soci(et)al aspect, the questions of the new "regions" (Central Hungary vs Budapest and Pest region); (2) regarding the economic aspect, the newly created territorial "units" (Economic Development Zones); and lastly (3) as a nature-focused aspect, the management of surface water.

These factors are directly connected to the five investment priorities of the EU for 2021-2027 i.e. Smarter, Greener and carbon free, Connected, and Social Europe that is Closer to its citizens (EC, 2018) and represent criteria that reflect the reality on the ground. These factors were examined in specific case studies exploring their relations to national and interregional policymaking and EU level policies also, together with their presence in the planned programming documents, e.g. the Operational Programmes and Partnership Agreement. As a result, we aim to identify some direct causal relations between policy and practice, highlight some synergies (or their absence) between national and interregional level sectoral (horizontal) and EU-Member State level (vertical) processes, and additionally, shed some light on the possible future scenarios in these specific and important areas. Through these outcomes, our research could contribute to a more tailored approach to regional development, that is a major objective of the New Cohesion Policy.
\end{abstract}

Keywords: EU Cohesion Policy, 2021-2027, territorial development, Hungary

\section{INTRODUCTION}

The EU Member States face various environmental, social and economic challenges, some of which are common and important at European level, while others are specific and limited to a few countries. Therefore, Member States face a dual challenge during their strategic 
programming activities: to comply with the general and overall EU priorities on the one hand, and to represent their country-specific interests on the other. Thus, it is a serious task for a country to coordinate its policies or to subordinate them to the plans and objectives of the European Union. In addition, unique interactions can also be observed, either a substantial change in policies of the countries as adaptation to the EU level, or parallels, sometimes even contradictions between the policies of the EU and the Member States. As a summary, several case studies can be observed and analyzed at national (Member State) and sub-national (for example regional) levels also. We can experience a growing self-confidence of the Member States (especially in case of Central and Eastern European countries, including Hungary) in parallel with the time spent as part of the European Union, so national governments are becoming more and more experienced and innovative in their strategic programming activities. This is especially true for cohesion policy, which is where both the geographic characteristics and the socio-economic structure of the country play an important role.

Our aim is to present how national (and/or sub-national?) level policies can answer different types of challenges in the EU programming period between 2021 and 2027 (geographical, soci(et)al-economical, and territorial). After more than 15 years as a Member State of the European Union, in our fourth programming period (2004-2006, 2007-2013, 2014-2020 and the current 2021-2027), how can different challenges be addressed and what could be learned from the strategic programming exercises of the last decades? Just to raise a basic question: in the current era of Green Deal, a competitive, green and digital Europe, sectoral, territorial, or integrated policies should deal with surface water, as a geographical factor, or it should be integrated to all of them, as a potential threat and opportunity at the same time? Or: which is the 'optimal' territorial scope (if there is such) to address the territorial, soci(et)al and economic questions, especially inequalities, and could the re-designing of a NUTS2 region or the formulation of a 'functional region' have any effect on these (as in case of Central Hungary: Budapest vs Pest County or the newly established economic zones)? Should these policies be elaborated with a top-down or bottom-up approach?

Thus, in the following, a geographically directly determined, nature-focused aspect and a societal-economic aspect will be analysed, both from the perspective of their policy relevance. The nature-focused aspect will be analysed through the management of surface water, while the soci(et)al-economic aspect will be analysed through two specific territorial-regulatory examples, namely the separation of Budapest from Pest County (as a former NUTS2 region) and the formation of the new, functional (?) economic zones (including the so-called Creative region initiative). 
The main research problems addressed are the followings:

- RP1: In Hungary the management of surface water is not handled in an integrated way, so surface water objectives are set in parallel from both sectoral and territorial perspectives, in different territorial frameworks, partly similarly to the European Union.

- RP2: The territorial inequalities within the country, especially as regards Budapest and the other parts of the country, have not decreased significantly despite more than 15 years of Cohesion Policy interventions and co-financing.

The main research questions are:

- RQ1: To what extent are the objective systems of sectoral and territorial policies similar and in which territorial framework are these planned?

- RQ2: Could the re-designing of regional (not administrative) borders and the creation of new functional territorial formations contribute significantly to reduced territorial inequalities?

These two main research topics were selected for two reasons: firstly, they represent the most important territorial characteristics of the country, and secondly, they represent the two main types of actual policy challenges, one geographical and one soci(et)al-economic. Thus, based on these typical challenges, possible policy answers could be analysed to them, for example their focus, approach, territorial level, funding, synergies and maturity.

Our paper has both theoretical and practical relevance as it studies the main spatial structure characteristics of Hungary, focusing on large territorial areas, social and economic concentrations and "fractures" of geographical space, and the question addressed is: if and how Member States can represent their specific issues and interests in the EU programming period between 2021 and 2027 through strategic programming activities.

\section{THEORETICAL BACKGROUND AND METHODS}

As our paper is very actual and has a strong policy-relevance, our empirical research relied mainly on the analysis of strategic programming and policy documents, development concepts and the connected national and EU level regulations from the near past and designed for the next EU programming period between 2021 and 2027. As regulations and tools concerning the 'new' programming period have not been covered with sufficient scientific outputs yet, a relatively limited scientific literature could be analysed and referenced in the paper. Based on the above, scientific and policy documents will be both analysed in this chapter. 
Starting with the relevant scientific outputs, as it is clearly stated by Bachtler et al. $(2019,2)$ in Towards Cohesion Policy 4.0, "The challenge for EU and Member State policymakers is to develop or adapt policy frameworks and strategies that will stimulate sustainable growth, in a manner that ensures greater inclusiveness, especially in access to employment and capacity for entrepreneurship. This demands a more granular approach to structural policy, tailored better to the specific conditions of the different types of regions and communities across the EU. Different strategies are needed for frontier regions, intermediate regions (some catching up but others only keeping pace) and lagging regions."

Now, we arrive to the next question posed by Crescenzi, Fratesi and Monastiriotis (2020): "How important are local- and national-level characteristics and policy choices in shaping the benefits produced by the policy and their distribution?" They also provide the answer: "As Cohesion Policy can only deliver as a three-layered system (EU-member states-regions). If member states are punching below their weight, the entire architecture is weaker and less politically sustainable." Contrary to the "blame Brussels" strategy they urge a shifted focus by the "new member states in Central and Eastern Europe (CEE)" from concentrating their efforts (and resources) on capital cities and their regions, and at the same time to achieve 'unity with diversity' in Cohesion Policy, they call for a process of 'policy discovery' to be initiated and directed at the national level in order to lead a reflection on the spatial development model of each member state (and its regions) within the framework of a strong EU-wide Cohesion Policy (Crescenzi et al., 2020).

And lastly: has European Cohesion Policy undergone a learning process in the last decades? According to some authors and recent works, the answer is yes (Rodríguez-Pose \& Novak, 2013; Fiaschi et al., 2018; Rodríguez-Pose, 2021). As it can be seen on Figure 1 Hungary is clearly one of the main beneficiaries of Cohesion Funds (with investment intensity around $€ 400$ per capita on an annual basis between 2007 and 2013), the effective use of these funds is of outstanding importance in 2021-2027 also. Recent research also emphasises the need for carefully-targeted, place-sensitive intervention in areas that are often perceived - even by themselves - as “places that don't matter” (Rodríguez-Pose, 2021).

Have Member States also undergone a learning process in the last decades? This is the main question to which our paper seeks the answer through studying the case of Hungary from the perspective of a typical geographical and a soci(et)al-economic challenge also. 
Figure 1 Annual investment intensity in less developed regions, 2007-2020

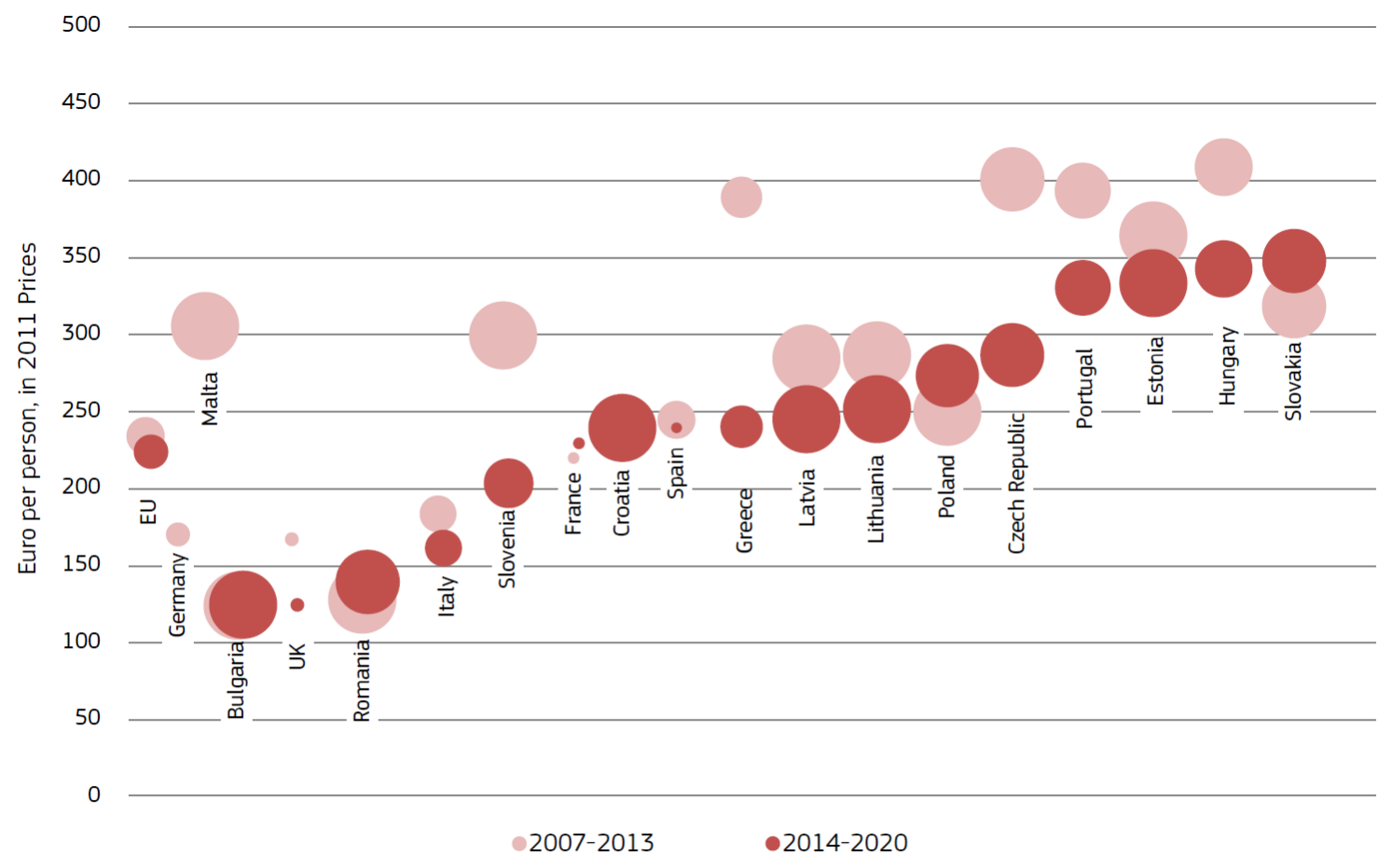

Aid intensity include ESF, ERDF and Cohesion Fund. Cohesion Fund aid intensity was assumed to be the same in all regions of a Member State receiving support.

Source: DG BUDG, SFC and DG REGIO calculations

Source: DG BUDG, SFC and DG REGIO calculations in Rodríguez-Pose, 2020.

Moving on to policy documents, it must be emphasized that EU priorities are changing from one programming (budgetary) period to the other, for example Europe 2020 has set 11 thematic objectives for the period of 2014-2020, EU cohesion policy has set a shorter, modern menu of 5 policy objectives supporting growth for the period 2021-2027 (EC, 2020b). On the other hand, the Hungarian Partnership Agreement for 2014-2020 has set out 5 national development priorities (PA, 2014), while in the Partnership Agreement for 2021-2027 more than 10 policy objectives have been identified (PA, 2021). Thus, controversial processes could be observed at the EU and national level in the specification of the main targets (development and/or policy objectives and/or priorities).

Regarding the planned policy answers at the national level, the Hungarian Partnership Agreement for 2021-2027, the National Development Plan and the Operational Programmes are the most relevant documents to be analysed. ${ }^{1}$ Starting with the main aims of the Hungarian Partnership Agreement, the relatively small-scale and open economy of the country generates

\footnotetext{
${ }^{1}$ At this point, it should also be mentioned that the European Commission is providing specific guidance and expectations to the Member States during the preparation and finalisation of the Partnership Agreements regarding both its structure and content, that can also influence the final document.
} 
both opportunities and challenges. Financial stability is present, and several structural reforms have been completed in the last decades. Additionally, the macroeconomic conditions are favourable for the absorption of Community funds in the next EU programming period between 2021-2027. The main focus point of the national development objectives for 2030 is the increasing of economic and soci(et)al competitiveness in parallel to the catching up of disadvantaged areas. The most important financial means are provided by the Multiannual Financial Framework (MFF), the Next Generation EU (NGEU) and the Recovery and Resilience Facility (RRF). Additionally, other programs financed from the Hungarian national budget also contribute to the achievement of these objectives, not exclusively the Modern Cities Program, the Hungarian Village Program, the Kisfaludy Program on Tourism, the "Catchingup Settlements" Program, and the National Environmental Remediation Program (PA, 2021).

In the followings, the most important elements of the national policy-level are summarized before the presentation of the specific case studies.

The most important policy-level and legal documents of territorial (regional) development in Hungary were the National Settlement Network Development Concept in 1971 [Government Decree 1007/1971. (III. 16.)], the National Spatial Development Concept in 1998 [Government Decree 35/1998. (III. 20.)], and 2005 [97/2005. (XII.25.)]. The Parliament Resolution No. 1/2014. (I. 3.) OGY National Development 2030 - National Development and Territorial Development Concept (OFTK), and the Act XXI of 1996 on Regional Development and Regional Planning (IV.5.) and its amendments are the decisive policy papers of today. From the viewpoint of our current paper, the new approaches of the National Development 2030 to territorial development should be emphasized, as follows (OFTK, 2014):

3.1.2.1 Mapping of macro-regional territorial connections

\subsubsection{Multi-centred development}

3.1.2.3 Urban-rural cooperation

\subsubsection{Spatial structure protecting our natural resources}

3.1.2.5 A spatial structure promoting investments

\subsubsection{Connecting peripheral territories to the country's social and economic "blood flow"}

\subsubsection{Autonomous territories}

3.1.2.8 The new medium level: a county's new roles

3.1.2.9 A city and its catchment area - the basic functional unit 
In the list above, the three most important aspects connected to our research are highlighted in bold. The visualization of goals is a widely used method in development policy, as an efficient tool to present both the current situation and specific objectives. In the following, two maps are presented in relation to the two main research strands of our paper: the management of surface waters as a geographically determined issue; and the territorial inequalities as a soci(et)al-economic issue. As regards the water catchment area, the visualization in the OFTK is referred, as indicated on Figure 2.

Figure 2 Water management

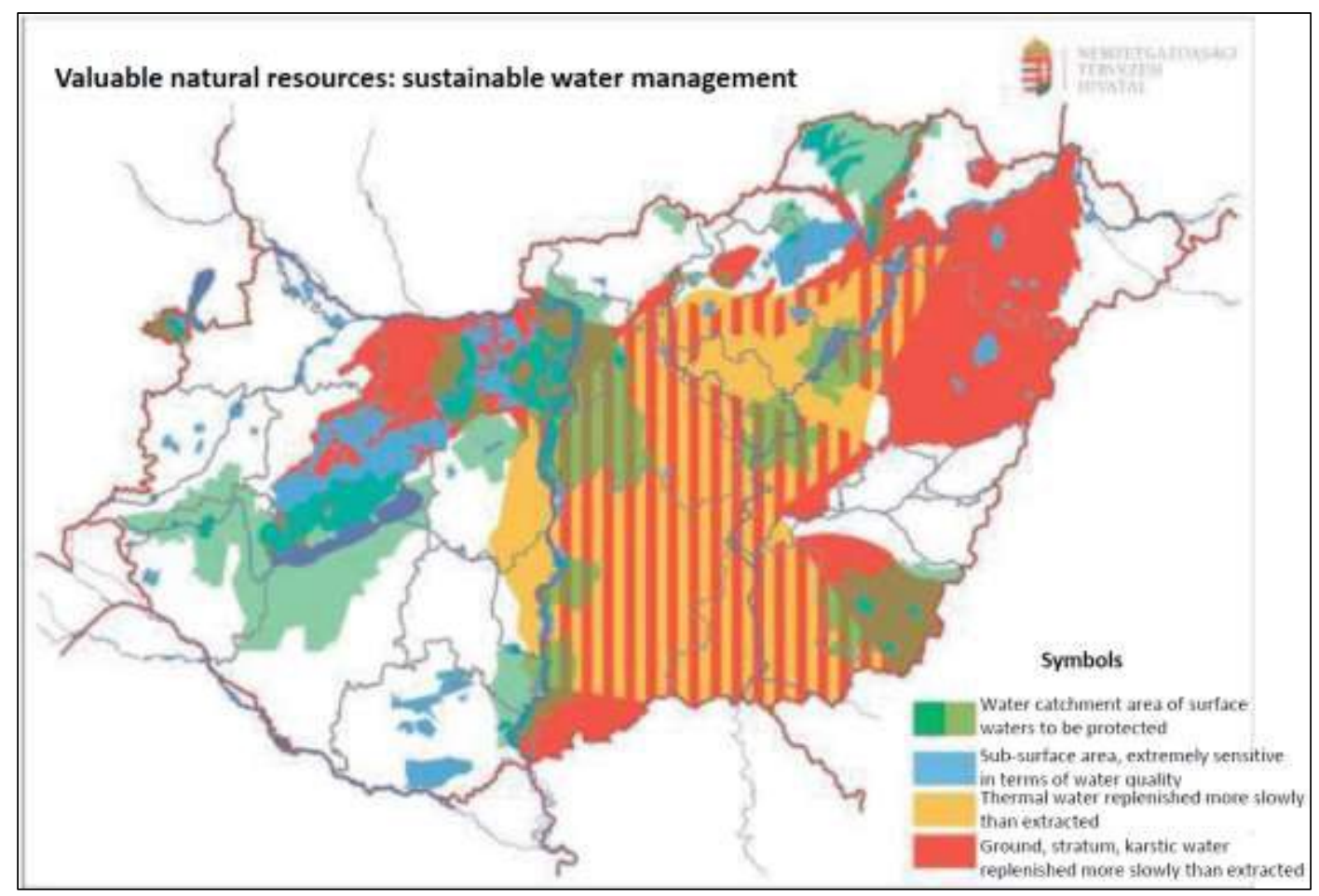

Source: National Development and Territorial Development Concept (OFTK), 2014.

As regards the predominance of Budapest and the connected peripheral territories in relation to the country's social and economic "blood flow", it is well-visualised on Figure 3 about the structure of strategic relations.

As referred above in the most important national level strategic policies and legal regulations, the Hungarian Government has declared several times that the reduction of territorial inequalities is a prioritized national objective. Additionally to these documents, the draft Partnership Agreement of Hungary with the European Commission for 2021-2027, and the following recent regulations also underline this intention (Evaluation report, 2020):

- Government Decree 1743/2018. (XII. 20.) on the specific tasks connected to the reduction of economic inequalities between the different areas of Hungary, 
- Government D+ecree 1206/2019. (IV. 18.) on the elaboration of the development programme necessary for the reduction of economic inequalities between the different areas of Hungary.

Figure 3 The structure of strategic relations in Hungary

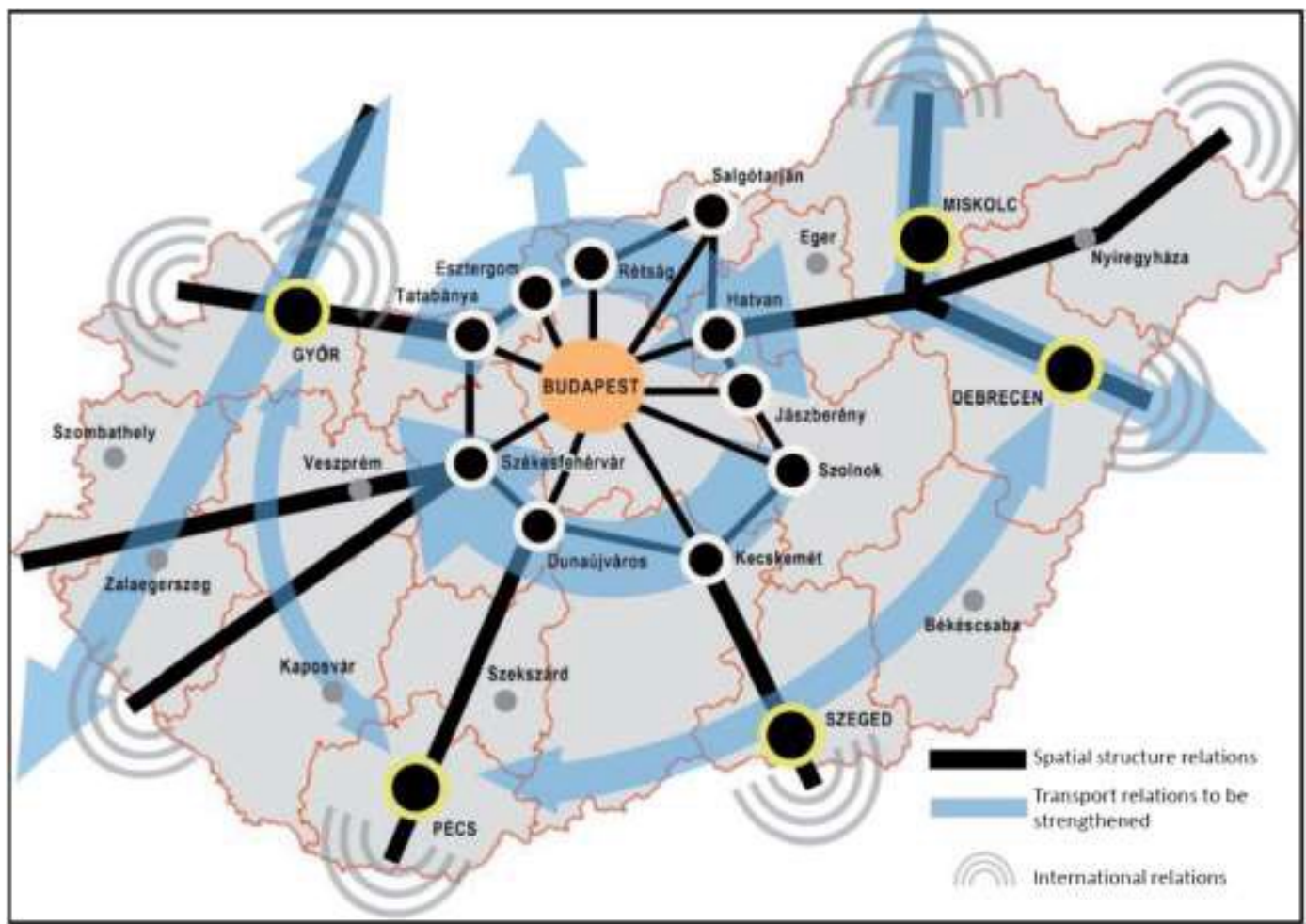

Source: National Development and Territorial Development Concept (OFTK), 2014.

Based on all the above, making Europe greener and more carbon-free together with the reduction of territorial inequalities will be a prioritized objective at both EU and Member State (Hungary) level in 2021-2027, so our research question is whether the strategic level objectives can be observed "in the field" also at Member State level through the studying of specific case studies.

Regarding the data and methods used in our research, our research mainly relied on the analysis of the existing (still relatively limited) scientific literature and the relevant EU and national level policy documents (as presented above). Additionally, in the next chapter (Results) the current standing point and conceptual system is presented in detail, connected to our main research questions. The overall objective of our research is to raise some relevant questions and generate research interest on this very actual and relevant issue, by shedding light on the Hungarian example through document analysis and secondary research. An in-depth analysis supported with statistical data and interviews could be completed in the future only, 
when some preliminary (mid-term) results and specific, measurable indicators will be already available, so this constitutes a possible future research direction.

In connection to our first research question (RQ1: To what extent do sectoral and territorial policies define the same objectives for surface waters?), the current status will be analysed in detail, based on the textual and conceptual analyses of the relevant EU and national level policies.

In connection to our second research question (RQ2: Could the re-designing of regional (not administrative) borders and the creation of new functional territorial formations contribute significantly to reduced territorial inequalities?), two recent initiatives will be presented as "case studies" and some relevant aspects will be analysed based on the information available so far.

In relation to surface waters, different policy papers of the European Union and Hungary can be examined, and this issue can be explored from two perspectives and in two territorial dimensions. On the one hand, it is possible to analyse how water management objectives are present at the level of the European Union and, within the same framework, how surface waters are reflected in the general system of regional policy. On the other hand, the water side and its territorial characteristics can be taken into account in Hungary, as well as the role of waters in regional development. In relation to the Metropolitan region of Budapest, our paper focuses on how national government level and local /county level actors react on the new administrative setting. The "divorce" of Budapest and the neighbouring Pest County has raised several technical, administrative, and practical questions for regional development policy actors. In relation to the economic aspect, the evolution process of the recently established new "economic zones" can be examined at the national level, together with some future plans and strategic programmes.

In the following, an analysis of the current policy documents was completed in connection to the first research topic (surface water management), while in connection to the second research topic (territorial inequalities), two case studies were presented and analysed (the Metropolitan region of Budapest and the new "economic zones"), as innovative territorial development interventions. The basic difference between them is that the former required a legislative change both at Member State and EU level, namely the modification of a NUTS2 region, while the latter is based on a functional redesign (regrouping) of the existing administrative and planning-statistical territorial units. 


\section{RESULTS}

\section{Analysis of the Situation}

The geographical, natural, social and economic characteristics of a country present challenges and opportunities for the country's territorial policy at the same time. As regards Hungary, the country has several distinct territorial elements that require (preferably) focused and integrated development policy in a top-down or bottom-up manner.

Starting from the complexity of the geographical space, the physical geographical, geomorphological picture is the first determining feature. Due to its location in the Carpathian Basin, Hungary has predominantly lowland and hilly landscapes, with a small number of low mountains, which are not obstacles to the territorial processes of society and the economy. Hungary is isolated from the seas; it has land borders. A more decisive factor - and most important from the perspective of our paper - is the issue of surface water and groundwater. In Hungary there is relatively dense river network, with opportunities and threats (flooding limited crossing possibilities, different economic functions etc.). There are also plenty of stagnant waters in Hungary, of which Lake Balaton is the largest lake in Central Europe. In addition to the possibilities (mainly tourism), there are also problems (for example drying up of lakes, high water level, the quality of the water). The wildlife of wetlands is also of paramount importance in Hungary (the Carpathian Basin is a separate biogeographical region in Europe), including the maintenance of biodiversity. Hungary is rich in groundwater, the utilization of which is most pronounced in the supply of drinking water, medicinal waters for bathing and industrial water. However, the threat to water quality (e.g. fertilizers) and the lack of water in some places are serious challenges. Due to these, water management and planning have played an extremely important role in Hungary's territorial, economic and environmental policy for centuries, and currently several policies include references to these waters, but an integrated approach is not present.

In social and economic terms, an important spatial structural feature is the dominance of Budapest and Central Hungary. Currently the capital city concentrates $18 \%$ of the population, while $37 \%$ of the national GDP is produced here, while the Central regions (Budapest and Pest County) figures are 31 , and $48 \%$ respectively (2019). The lack of big cities is a prominent feature of the Hungarian spatial structure; the second-tier cities (8) have only 100-200 thousand inhabitants each. Slow agglomeration processes can be detected around some of them, but the Budapest agglomeration alone is of such a size compared to the country (2.5 million people with the capital) that it can be treated as a key spatial structural element. (According to Eurostat, 
it is one of the 20 largest urban regions in the EU, and the only one from the cities of the Eastern Member States.) The situation is similar in terms of economic role and relations: even regional centers (5 large cities) do not show a prominent economic zone (Berkes, 2020). On the other hand, it is important to emphasize that the Budapest metropolitan area is not a homogenous and highly developed space, with $21^{\text {st }}$ century services available everywhere at low cost. Even the Capital city has internal structural problems (for example lacking infrastructure elements, overburdened and underutilized areas, extensive brownfields), while there are lagging microregions in Pest County's fringe also, and internal peripheries outside the agglomeration settlements' ring adjacent to the capital. Farther we go from Budapest, more similarity can be detected to the neighbouring counties. In a historic context it becomes obvious that after World War I. - with the formation of new countries and the drawing of new national borders - all counter-pole cities have become parts of sovereign neighbouring countries (Zagreb, Bratislava, Kosice, Cluj etc.). Several regional development policy actions have been carried out in the last 70 years to slow down the pace of agglomeration and suburbanization processes in and around Budapest. They have had limited results, presumably because of Budapest's long-lasting central role and population weight.

Regarding territorial development in the country, it can be said that on regional level it is characterised by a developed North-Western and Central Region and an underdeveloped Southern Transdanubia and Eastern Hungary (Pénzes, 2014), and on micro-regional level there are 31 beneficiary districts (járás) formed from 174 districts, as identified by Government Decree 290/2014. The development of the lagging behind areas of Hungary has been a priority since the change of regime (1990s), and all national governments have been continuously trying to achieve the development of these disadvantaged areas with various means. Since its accession to the European Union in 2004, several Cohesion Policy funds and the connected programmes, institutions and instruments have been introduced and set up in the country with mixed experience (Nyikos \& Soós, 2020).

For the sake of complexity, it has to be mentioned that Hungary also has a distinctive political geographical feature: it is neighbouring seven countries, five of which are EU Member States and three are members of the Schengen Zone. In our era, with special respect to international migration processes, this aspect is gaining more and more importance (in line with highlighted EU priorities on border management and security, for example). In connection with the border issue, it is also important that about 2 million Hungarians live outside the borders of Hungary (Megyesi \& Péti, 2019), in the Carpathians and the Carpathian Basin, and a significant part of them on the immediate other side of the borders. For these reasons, the Hungarian 
government has always paid special attention to the border zone and the Hungarians living abroad.

Overall, the spatial structure of Hungary is not complicated, but it has some striking elements: the quantity (and quality) of the surface waters, the weight and internal division of the capital region, the differences in territorial development and the state borders of the country. Dealing with these issues has long required an appropriate policy in Hungary. The question arises: which of these fit into the new objectives of the EU for the next programming period (2021-2027). In this paper three of the four main phenomena are highlighted, the role of country borders and cross-border relations that go beyond the scope and limitations of the current paper, so this specific feature of the country is not analysed further. (In the European Union, the Interreg program is specifically aimed at the development of the border areas, and although the financial means of this policy are not outstanding, they have an increasing tendency in volume and importance both, that is favorable for Hungary.)

\section{Water Management and Regional Policy}

Surface waters have always played an important role in the development of settlements and areas, but over the centuries their roles and functions have changed, and the surface waters can be both an opportunity and a risk. Currently there is social, economic need and political expectation to deal with them. However, even in this case, both sectoral and territorial policy is interested in it, so territorial issues in water policy and water issues in territorial policy can be found.

As regards the European Union, from the sectoral point of view, the following can be stated. The definition of surface water can be found in the EU Water Framework Directive (WFD, the "Directive 2000/60 / EC of the European Parliament and of the Council establishing a framework for Community action in the field of water policy"): it means a discrete and significant element of surface water such as a lake, reservoir, a stream, river or canal, part of a stream, river or canal, a transitional water or a stretch of coastal water (EC, 2020c).

With the entry into force of the Water Framework Directive in the European Union, the European Union's water policy was born, which is an important part of its environment policy (Szilágyi, 2019). In the EU multiannual environmental action programmes set the framework for future action in all areas of environment policy. They are embedded in horizontal strategies and taken into account in international environmental negotiations. Environment policy has recently been moved to centre stage in EU policy making, with the European Commission launching the European Green Deal as the main driver of its economic growth strategy (EC, 
2021a). Some parts of this are water-related, but the focus is more on the atmosphere: reducing greenhouse gases. Surface waters are more likely to be affected by climate change, with some estimates that 80 percent of the effects of climate change affect waters. As a result, the potential for development of surface waters is less pronounced, because the emphasis in development policy is not on repairing damage but on preventing it.

The issue of quantity, quality and biodiversity can be observed in the European Union's water policy and in the WDF. The policy encompasses an integrative approach, many elements of the hydrological cycle as well as different types of water use, which should be taken into account in the planning and operation of other EU policies. In addition, including a combined approach, its control methods include both the regulatory model for individual emissions and the (immission) regulatory model for water quality standards, as well as quantitative water protection, recognizing that there are close correlations between these sides (Szilágyi, 2018). Here, the essence of territoriality is that regulation is based on river basin districts and is not based on the classical administrative units (NUTS) of the Member States. From a sectoral point of view maritime policy plays an important role in the EU, but Hungary does not have contact with the sea, so it will not be addressed.

It can be emphasized that the European Union is in line with the UN recommendations. In 2015, the Seventh UN World Forum adopted 17 Sustainable Development Goals, including: "By 2030, achieve universal and equitable access to safe and affordable drinking water for all" (UN, 2015). It contains quantitative issues (sustainable withdrawals and supply of freshwater), quality issues (improving water quality), and biological issues (protecting and restoring waterrelated ecosystems). In addition, territorial objectives can also be found here, both at international (expanding cooperation and capacity-building), regional (implementing integrated water resources management) and local level (supporting and strengthening the participation of local communities in water management).

From a territorial point of view, in the new cohesion policy of the European Union the water issue is not dominant, whereas cohesion policy is also in line with the EU's overall objectives. The role of waters can be investigated in the case of the official macro-regional strategies in EU. [A macroregional strategy is an integrated framework endorsed by the European Council, which may be supported by the European Structural and Investment Funds among others, to address common challenges faced by a defined geographical area relating to Member States and third countries located in the same geographical area which thereby benefit from strengthened cooperation contributing to the achievement of economic, social and territorial cohesion (EC, 2021b).] Three of the four EU transnational strategies are related to water: the 
Baltic Sea, the Adriatic-Ionian and the Danubian cooperations. Here, however, in contrast to water policy, administrative units (countries, NUTS regions) form and delimit macro-regions. These are bottom-up initiatives, and the community of participating countries and regions is based on the principle of common waters and their use (Szabó, 2017).

As for Hungary, its hydrography is basically determined by the fact that it is located in the middle of the Carpathian Basin, surrounded by the Carpathian Mountains. In Hungary, there are 9,800 watercourses in the water register, and surface water gravitates towards the southern center, and from there it flows into the Black Sea via the Danube. The whole area belongs to the Danube catchment area. This feature of the basin also points out why this phenomenon is so important in the life of Hungary. Due to the continental climate, the water regime fluctuates: both flood (and inland water) and low water levels are present, and only $28 \%$ of watercourses are permanent. The average water flow of 29 rivers exceeds 1 cubic meter/second, the Danube $\left(6500 \mathrm{~m}^{3}\right)$ and the Tisza (820) and Drava (670) stand out. There are about 3,500 lakes in Hungary, of which $25 \%$ are natural and $75 \%$ artificial. Of these, Lake Balaton stands out, which is the largest lake in Central Europe $\left(592 \mathrm{~km}^{2}\right)$. Other larger lakes include Lake Tisza (121), Lake Fertő (315, but $75 \mathrm{~km}^{2}$ is in Hungary), Lake Balaton II. reservoir (52) and Lake Velence (26) [BM 2017 (Kvassay plan)] (Figure 4).

Figure 4 Hydrography of Hungary (rivers and lakes)

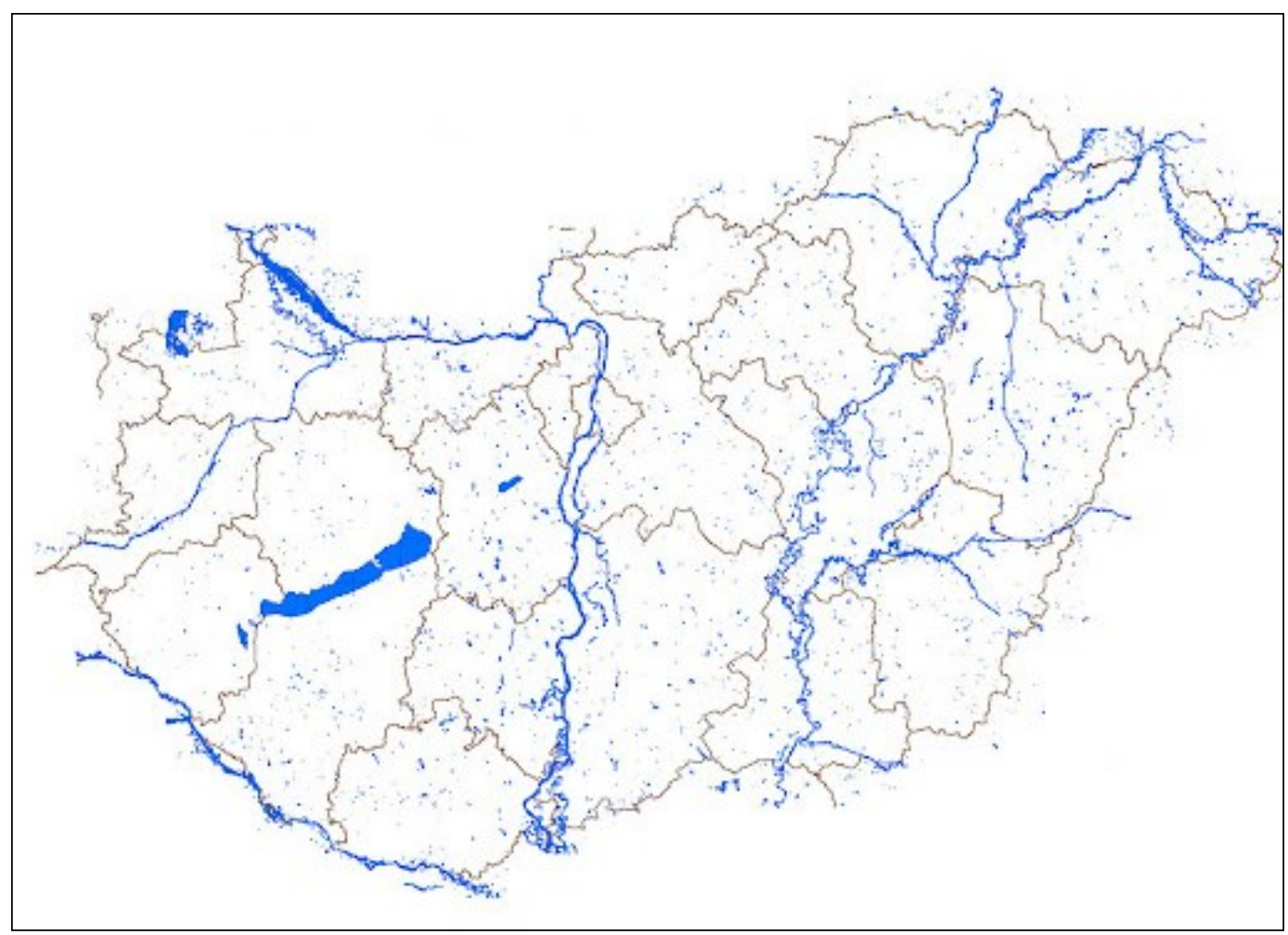

Source: https://tudasbazis.sulinet.hu/hu/ 
The role of water as a natural resource has changed in Hungary, it has been relegated in several respects, but at the same time its new functions have been strengthened. On the one hand, drinking water from surface watercourses is approx. only $12 \%$ and $88 \%$ is coastal filtered water. Residential water consumption has changed, the consumption of bottled (groundwater) mineral water has increased. On the other hand, in 2016, commercial fishing officially ceased in Hungary, but the role of fish farming increased (regarding the size of the area used and the amount of fish). The role of shipping is significant only in the case of the Danube and Lake Balaton (in the case of other surface waters only local tourism and recreation are significant), and in recent years the role of domestic passenger and freight transport has decreased. Agricultural water use for irrigation has substantially decreased in the last few decades $(90 \%$ of the used water is surface water), however, due to climate change, this trend may be reversed. The major user of water is industry (e.g. industrial cooling water, food industry), but due to industrial restructuring, some water-intensive industries (e.g. metallurgy, sugar industry) have been pushed back, while battery manufacturing is emerging as a new, water-intensive industry. The energy utilization of surface waters is negligible in Hungary (it accounts for $0.7 \%$ of electricity production), there are only small hydropower plants with local significance.

In addition to the declining economic role, the demand of society for the utilization of surface waters is strengthening. This is basically related to recreation and tourism. It includes bathing tourism, water sports, ecotourism, and fishing, which is especially popular in Hungary. (700,000 registered anglers were registered in 2020, which is more than $7 \%$ of the population (mohosz.hu).) Domestic tourism stagnated in the 2010s, about 14 M trips were recorded in 2019 (about $60 \mathrm{M}$ days). Although the number of domestic tourists has decreased due to the epidemic situation, similar values can be expected after the situation improves (in 2020 summer). The main destinations of domestic tourism are directly or partly surface waters, and Lake Balaton is the second most visited destination after the capital. Their weight is increasing due to the epidemic. Regarding the environment, the wetlands and their wildlife, and biodiversity have also played an increasingly important role (Hungary signed the Ramsar Convention). The role of related ecotourism has also increased. Overall, the role of surface waters in Hungary has changed, but has remained important, so it is present as a key development policy goal in Hungarian policies, but its weight and forms have changed from policy to policy.

From the sectoral point of view, the National Water Strategy, the so-called Jenő Kvassay's plan (2017) (prepared by the National Directorate General for Water Management (NDGFM) under the Ministry of the Interior (BM)) can be highlighted, the task of which is to set goals related to water management and status, to identify the measures and tasks required to achieve 
them, and to determine the conditions and method of implementation. The scope of the plan is all water-related activities throughout the country. In order to achieve the objectives set out in the Water Framework Directive, Hungary had to prepare a strategic plan and a program of measures. Within this framework, after the first (2010), the second (2016) river basin management plan, the third river basin management plan (2021) is now being prepared by NDGWM (which institution is part of the state administration). The objective of this plan is to reconcile measures to ensure the achievement and maintenance of the environmental objectives of the WFD with the needs of agriculture, energy production, shipping, tourism, climate adaptation, sustainable water management and rural and regional development.

Water management operates at the regional and municipal level in Hungary. In the first case the deconcentrated units of water management (12 offices, subordinate to NDGWM) belong mainly to the catchment areas, crossing the administrative borders of counties (Budapest and 19 counties are in Hungary) (Figure 5). Its tasks are multifaceted, including flood protection, water management, river, lake and inland water management, regional water distribution, protection of wetlands, etc. At the level of settlements, drinking water supply, water base protection, wastewater treatment, rainwater management etc. are the main tasks of the local self-governments.

Figure 5 Areas of the regional water directorates (a) and the counties (b) in Hungary

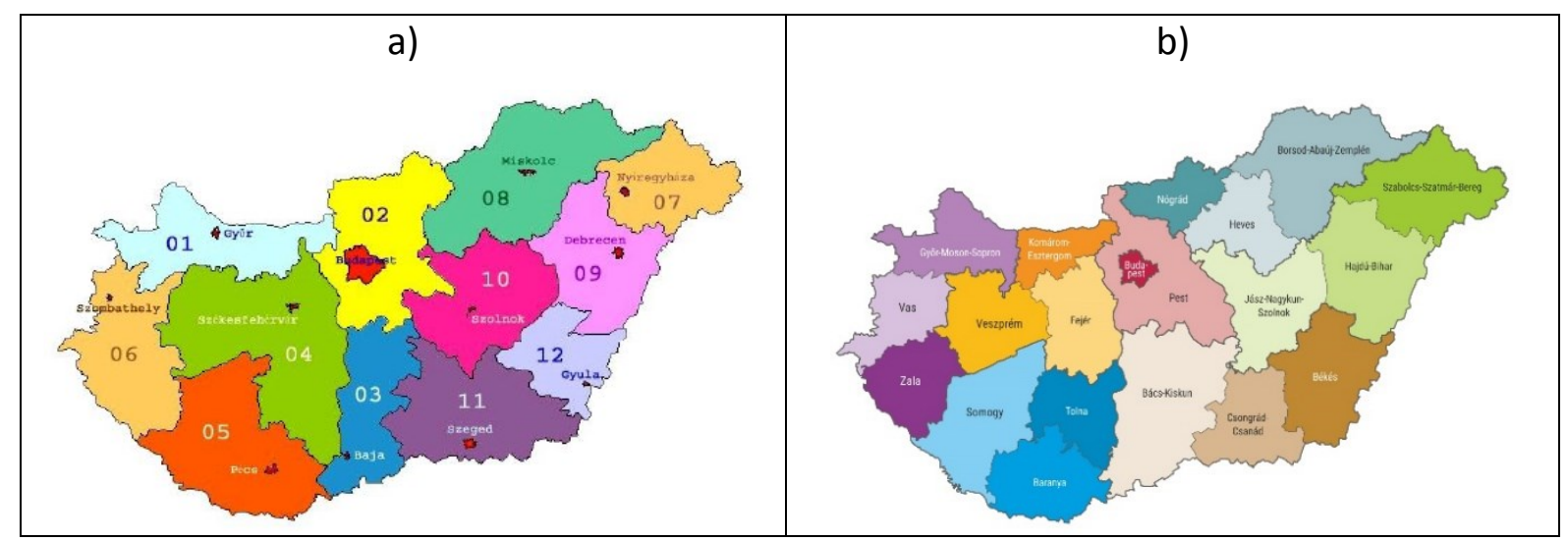

Source: Hungarian Central Statistical Office, National Directorate General for Water Management.

As it is transparent, a variety of tasks appear at different territorial levels, some of which appear in the state administration (planning built on WFD and implementations) and the other part in the case of local governments (mandatory tasks). In the second case, because the surface water is managed by the state water management, the settlements are limited actors. (County governments can plan with it, because the developments depend on the state water management.) 
Approached from the point of view of territoriality, firstly it can be stated that the XXI. Act on Spatial Development and Spatial Planning does not deal with surface waters, but its first version (in 1996) highlighted and treated Lake Balaton separately, as a special area of regional development, which has been the case ever since. A Government Decree (218/2009) on the content requirements of the regional development concept, the regional development program and the spatial planning plan takes into account many factors when recording the analysis of the area's endowments and internal resources, and water management appears as a separate point, but is not detailed in the text. As stated in the Kvassay plan, it would be expedient to make specific content requirements for the water management chapter of the regional development plans. This reflection is an indication that documents and actors in the two policies are not completely isolated.

The current National Development and Territorial Development Concept (OFTK, 2014) deals with surface waters. In the situation analysis, the issue of surface waters is emphasized in the environmental block (but it is also present in several economic sectors), and in the end formulating medium-term goals such as water protection, integrated, sustainable water management, and a longer-term change in water management. The long-term goals set out in the points do not include surface water, only the sustainable use of our natural resources and healthy drinking water supply, and these appear in the detailed objectives of the 13 specific objectives, complemented by the protection of drinking water bases, the improvement of water quality and the management of water in line with the landscape. On the other hand, the development of the Balaton area, as one of the areas of outstanding landscape value, appears separately, detailing the development policy tasks._Among the five-point medium-term development priorities, under the aim of increasing resource and energy efficiency it is mentioned that the role of sustainable resource use and water management in preserving the quantity and quality of natural resources must be given priority. Among the target groups further detailed for the period 2014-2020, water management will appear separately in the chapter on the protection of our natural resources. Among the target groups further detailed for the period 2014-2020, a separate chapter deals with the effects of climate change and water management among the policy tasks of conservation and sustainable use of strategic resources. The following appear as development policy tasks: sustainable water resources management, quantitative and qualitative protection, application of drinking water-saving technologies, wastewater treatment and utilization, mitigation of the effects of floods, droughts (water retention), etc. These are accompanied by territorial priorities: Lake Balaton, Danube Valley, Tisza Valley, Homokhátság (sand ridges). 
In Hungary, on the one hand, regional development plans are being prepared for the counties, and on the other hand, plans can be prepared for specially designated areas. In the case of the former, different formations of surface waters appear with different weights in the documents, as the administrative boundaries of the counties do not coincide with the boundaries of river basin districts, rivers separate the counties only in some cases. The Danube itself affects seven counties and the capital, while Lake Balaton covers three counties. In the case of special areas of development, however, five of the current ten Territorial Development Councils (bottom-up organizations) are linked to surface water (Lake Balaton, Lake Tisza, Lake Velence and Lake Danube Bend, Upper Danube and Szigetköz) and one area of traditional water scarcity (Homokhátság) (Figure 6). Of these, the Balaton Development Council is the oldest and appears separately in the Regional Development Act, since 1996. However, these bottom-up organizations do not have adequate financial resources, the counties are the priority units of regional development. However, there are different government territorial designations (such as tourist areas) through which some areas receive public funding.

Figure 6 Territorial Development Councils

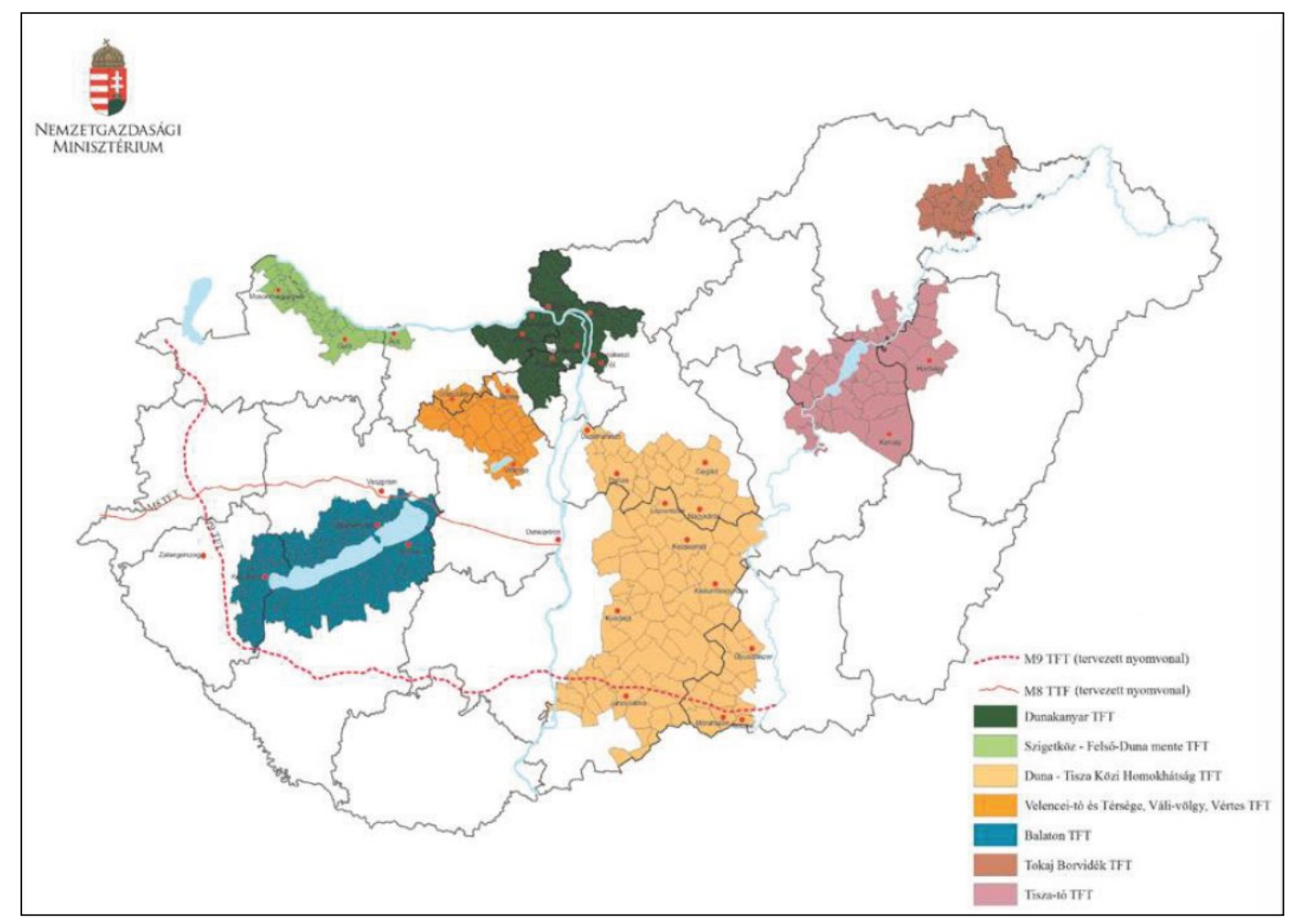

Source: Ministry of Economy. 
In Hungary, as a response to climate change, the national climate strategy has been completed, and the preparation of counties' and municipalities' climate strategies has started in recent years, through various content guidelines. This is related to the Green Deal, also in that the role of waters is subordinated to the atmosphere, as in EU documents (see there for reasons).

Hungary is a member of the Danube Macro-Region (macro-regional strategy) (Figure 7). A paper by Gál, Lux and Illés (2013) provides a comprehensive analysis of the Region. The strategy, which brings together 14 countries, aims to coordinate development policies in 11 areas to improve the region's connectivity, promote environmental protection, increase prosperity and strengthen the region. Hungary has taken on a coordinating role in three key areas: promoting sustainable energy with the Czech Republic, restoring and conserving water quality with Slovakia, and managing environmental risks with Romania. The participation provides an opportunity for the development of the Danube and its region.

Figure 7 Danube Macro-Region

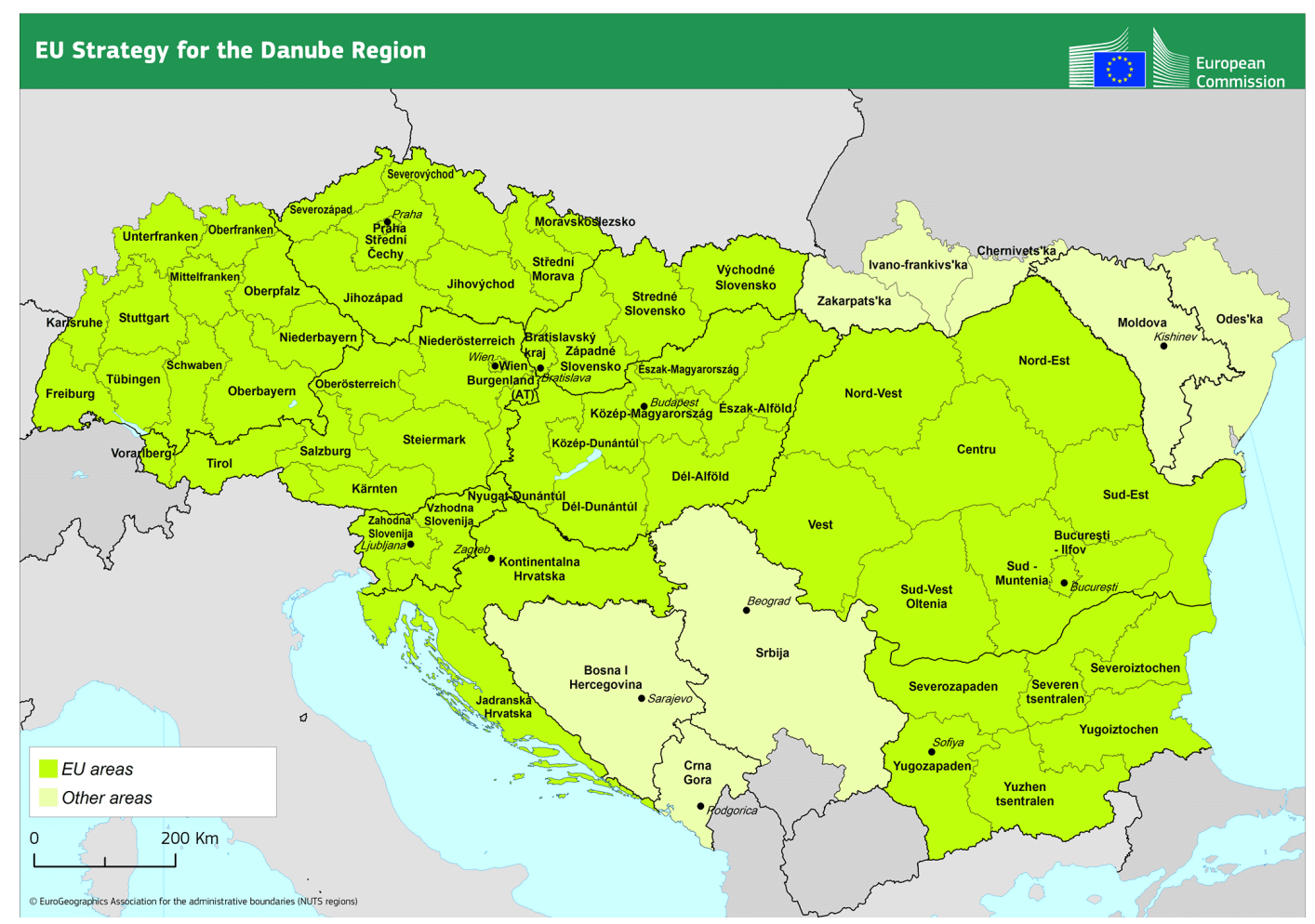

Source: https://danube-region.eu/about/

For the next EU period, the partnership agreement (draft) and the operational programs can be studied on the one hand, and the recovery plan on the other. These have not been finalized at the time of the current study, so minor changes may still occur.

Water has an appropriate role in the Hungarian Partnership Agreement, it appears in several parts and forms. Of the five policy objectives, a greener Europe appears, such as the 
development of infrastructure for water management that addresses both water abundance and drought; in the field of disaster management, the development of disaster resilience is needed. In addition, it is related to surface waters that the efficiency and development of public utilities providing drinking water and wastewater treatment still need to be developed. Related to this are the goals of protecting the aquatic ecosystem, increasing the number of native fish stocks in the waters, and protecting water quality. Overall, integrated water management is the goal. In the case of delimitation agreements and issues between each operational program (water management and disaster management, climate adaptation part), it is emphasized that: disaster management and regional, large-scale water management developments and stormwater management, as well as stormwater management related to major water utility developments, can also be supported only in the KEHOP (Environmental and Energy Efficiency Operational Program). TOP plus supports local, settlement-level stormwater management (e.g. stormwater reservoirs) and small-scale water management.

The Summary of Hungary's Recovery and Adaptation Plan (draft) emphasizes that water management is a key area for the future of Hungary and Europe, where it is essential to develop and strengthen an optimal and sustainable system in line with the country's natural conditions. In the draft, component $\mathrm{D}$ is about water management itself, although its essence is limited to irrigation and abstraction: the proportion of irrigable agricultural land must be increased, and farmers must have legal access to water resources. In component $G$, which deals with the transition to a circular economy, wastewater treatment appears in smaller settlements: they are connected to a sewerage agglomeration or a sewage treatment plant, several small settlements may decide to build a common sewerage network and sewage treatment plant.

\section{The Question of the Metropolitan Region of Budapest in Regional Policy}

Regarding multi-centred development, the research of Nemes-Nagy and Tagai (2009) is referred mainly, that analysed in detail the GDP/capita volume in connection to regional inequalities (centre - periphery).

Figure 8 quite clearly visualises the inequalities of the economic structure and highlights the difference between Budapest and the other NUTS3 level areas (counties). The Capital city can be characterized with above average GDP/capita figures, followed by the North-Western counties, that are situated much closer to the core areas of the EU than to Budapest. Even Pest County is losing pace compared to the latter. At this point it should be emphasised also that Budapest's outstanding numbers are to be dealt with due methodical carefulness, as GDP over- 
measures the City's real output and distorts the aggregated figures (since nationally active companies' output is booked at Budapest).

Figure 8 The dominance of Budapest and the dissected development of Hungary

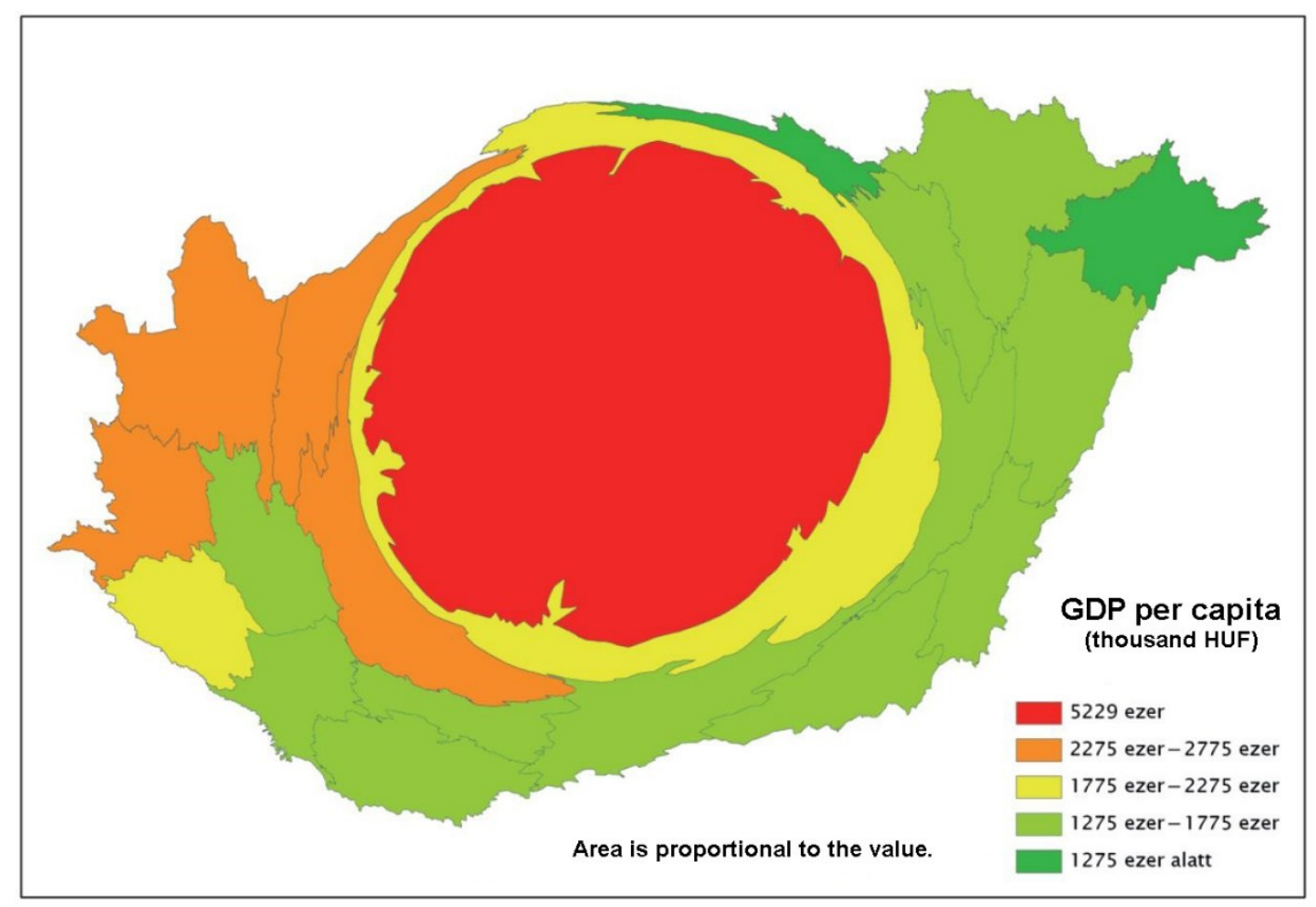

Source: Nemes Nagy \& Tagai, 2009.

In the last decade the basic pattern has not changed substantially: Budapest's economic output is still ahead of the national average, the North-Western part of Hungary is catching up, and partly some Southern-Eastern counties have started to catch up. However, Pest County's economic development has slowed down, partly because of global economic backward effects, and partly because of the adverse effects of its "developed" status in the former Central Hungary Region (NUTS2). Resident companies could not have been able to embark upon the state subsidies levering the development of the Convergence regions' companies. Pest County's economy could have relied - until the new 2021-2027 programming period - on its own and Budapest's financial resources.

According to the OFTK (2014) Budapest metropolitan region needs special attention as it is the most competitive and service-oriented area of the country. Development policy should utilise its resources to keep its growth potential and enhance the competitiveness of its economic actors. It can be achieved partly by 'traditional' infrastructure development tools (encompassing linear as well as human infrastructure elements), and partly by economic incentives for companies. Special attention should be given to R\&D and human resources 
development. The complex and heterogenous composition of the Metropolitan area needs special attention and territorially focused development interventions.

In 2020 Central Hungary Region (NUTS2 level) was split into two parts: Budapest Region and Pest County Region. Thus, the latter has become eligible under Convergence regions category for the least developed areas of EU Cohesion Policy. However, the new administrative and development policy settings have not been created yet: no new coordination forums have been set up and no reconciliation ways outlined until now. Until 2013, the Central Hungary Regional Development Council was to undertake the above tasks at NUTS2 level. After its withdrawal the Regional Reconciliation Forum has been set up, as in all other NUTS2 regions, containing the representatives of Pest County Municipality and Budapest Municipality. After 2020 both entities have become separate NUTS2 level organisation, thus the Forum has been dissolved. Formally, no new institutions or delegate bodies have been set up to substitute the above organisations. Informally, the two entities are free to establish any type of negotiation forums, however it will not solve the legislation 'gap' raised by the split of former Central Hungary Region. We presume that this will not hamper substantially the socio-economic development of the Metropolitan region, since it is well embedded in the world economy, however, the lack of coordination might entail a loss of resources, and it may lead sub-optimal solutions in problem areas affecting both entities. An in-depth analysis and future scenarios can be found in the recently revised version of Pest County's Development Concept 2030 (Pest County Development Concept, 2030, 2021).

In the 2021-2027 programming period EU Cohesion policy aims to concentrate more on the disadvantaged regions. Pest County, as new region, is in-between the developed and lagging behind areas, however its' peripheral micro-regions are not different from the neighbouring counties or their settlements. The inner circle agglomeration settlements are more like the Capital cities' outer districts, they are suburban spaces under transformation. Regional development policy and development tools must address well this heterogeneity. It has a crucial role in creating missing infrastructure elements (suburban railway links, $\mathrm{P}+\mathrm{R}$ and workplaces locally, while keeping pace with the human infrastructure in the fast-growing suburban settlements.

The Metropolitan region's economic background is quite robust in comparison to the other regions of the country. Many national company headquarters are located in the agglomeration area, and several sub-centres of multinational companies are seated here as well, in many cases they have management role on CEE and SE European level. The same issues and the relationship of globalisation and metropolization in other capitals in Central and Southeast 
Europe have been recently examined by Rácz (2019). Many companies in Budapest have local suppliers and most of them have lively local linkages with each other. Thus, it can be inferred that the vast majority of the region's economy is not dependent on EU Structural and Innovation Funds, however, they may have a beneficial effect on their operation. On the other hand, there are micro-regions where the availability of non-repayable funds is the prerequisite of balanced and steady growth. In non-agglomeration areas of Pest County/Region the absence of state subsidies would hamper the development of small and medium-sized enterprises. Missing linkages and non-adapted administrative structures on metropolitan level may cause suboptimal utilisation of development resources and may result in lower economic growth in total, while preserving the structural problems of inner peripheries (even in the Budapest itself) and reproducing the poor integration of outer micro-regions. Based on the above, Figure 9 and 10 illustrate the regional aid maps of Hungary for 2014-2020 (extended until 31 December 2021 by C(2020) 6769 Decision of the European Commission on 7 October 2020) and 2022-2027 (approved on 16 September 2021 by the European Commission). The Hungarian regional aid map was among the first maps approved by the European Commission within the framework of the revised Regional Aid Guidelines (RAG) and introduces a significant difference: the 50\% maximum state aid ratio for Pest County.

Figure 9 Regional Aid Map of Hungary for 2014-2020 (extended until 31 December 2021)

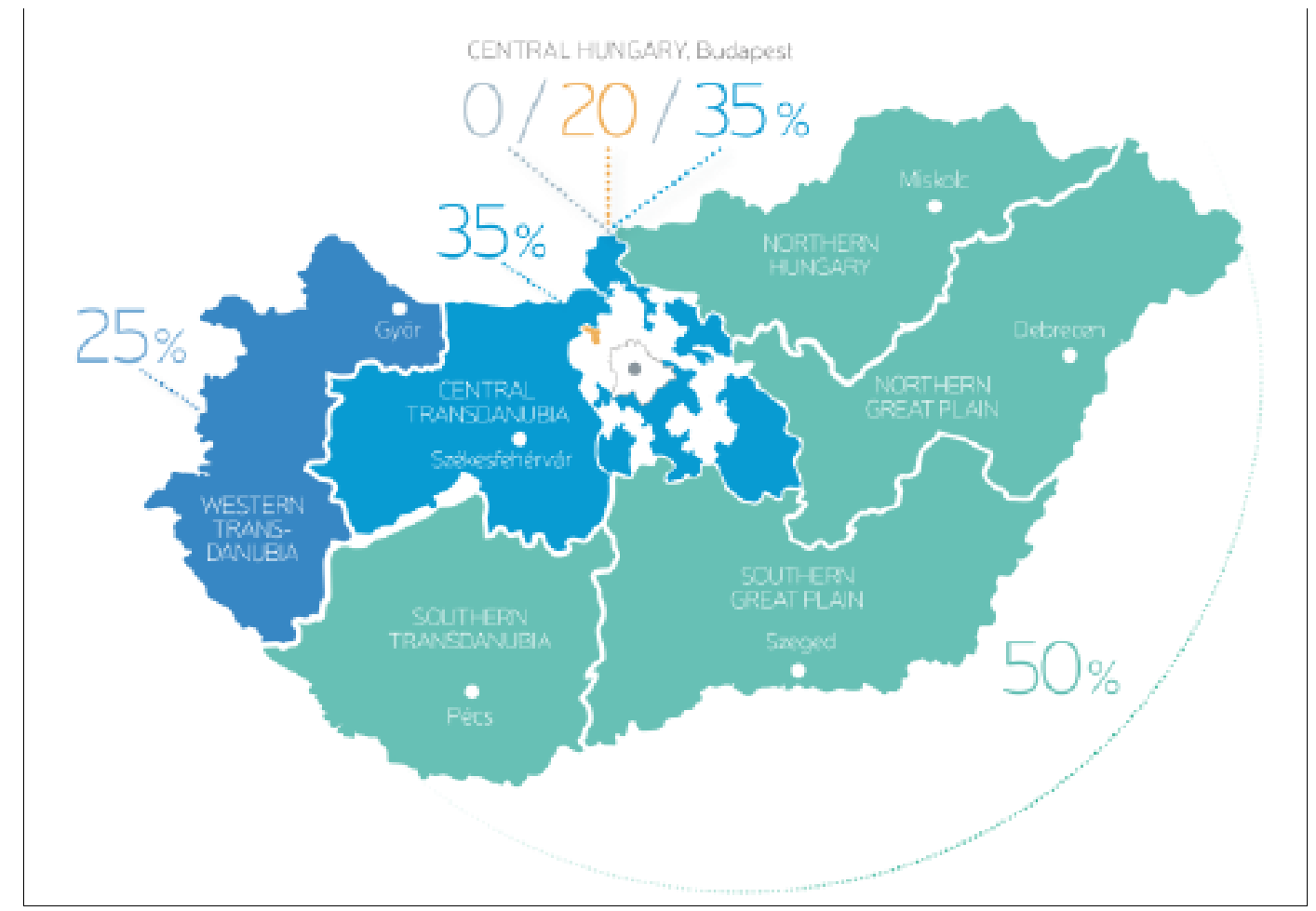

Source: Hungarian Investment Promotion Agency (HIPA), 2021. 
Figure 10 Regional Aid Map of Hungary for 2022-2027

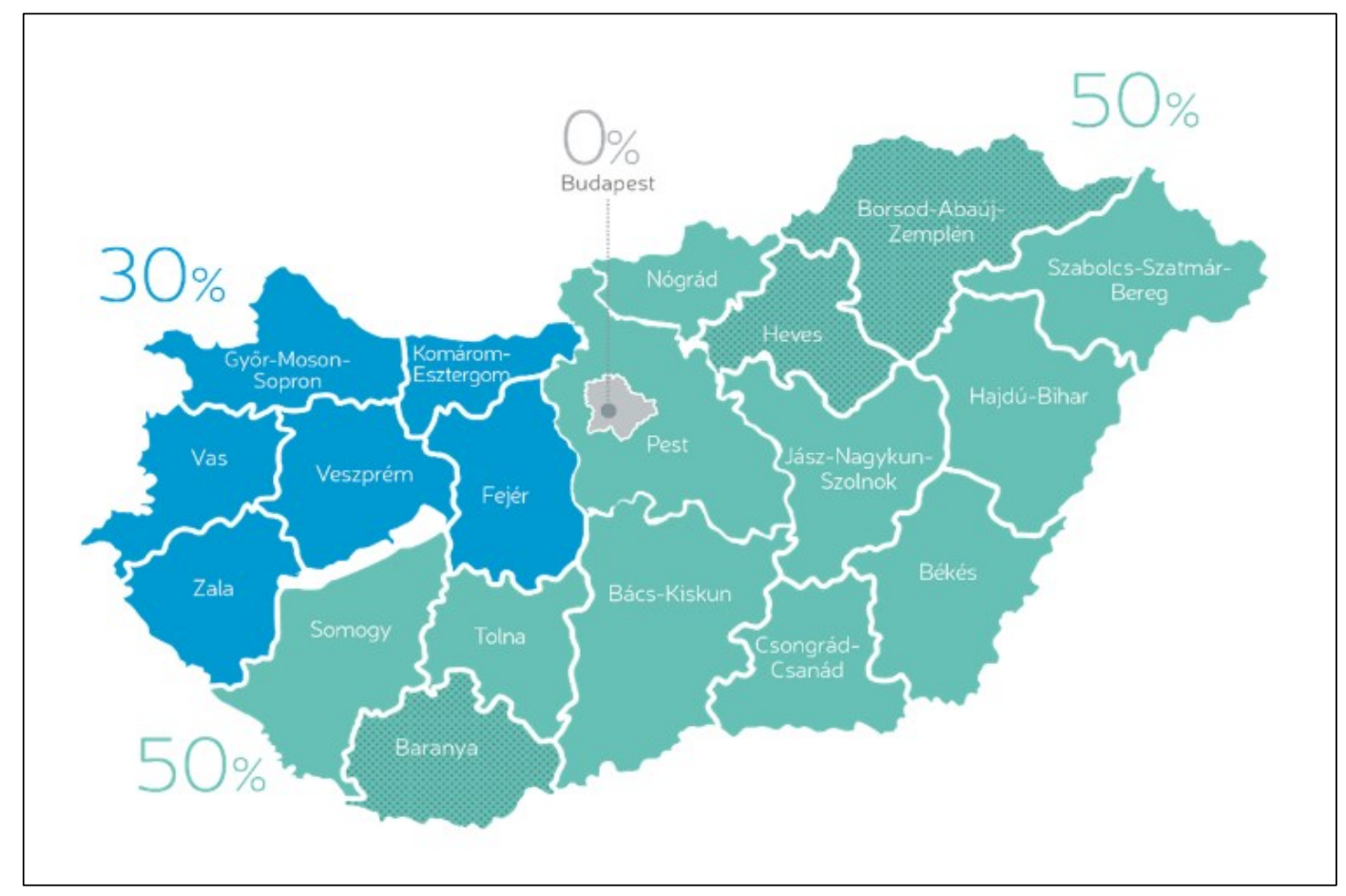

Source: Hungarian Investment Promotion Agency (HIPA), 2021.

This is the maximum available state aid ratio within the European Union for the investment activities of large companies, and it could generate a positive impact on the processes and challenges analysed formerly.

\section{The Economic Aspect and the Newly Created Zones versus Regional Policy}

As described above, the areas of Eastern Hungary and South Transdanubia are economically backward in Hungary, but the territorial picture can be further refined to the district level (31 underdeveloped districts in Hungary, Government Decree 290/2014) and to the settlement level (Figure 11). The latter, while showing the macro-regional differences, also shows that the picture is mosaic in places (Pénzes, 2014). Thus, by drawing boundaries that do not consider the existing administrative (county, district) boundaries, but focus rather on functional characteristics, new, more suitable development areas can be demarcated. Such areas could be designed with a top-down and bottom-up approach also. Typical top-down areas are the Lake Balaton, Tokaj Region, and the Middle Danube Region. These are direct beneficiaries of national and EU state aids, while the ones generated with a bottom-up approach are normally less prioritised by non-refundable cash subsidy schemes.

The national vision stated in the OFTK (2014) is the following: "In 2030, Hungary will be a leading economic and intellectual centre in Central and East Europe, ensuring that its residents 
can make a stable living, with a competitive economy based on the sustainable usage of resources and, in connection with that, an increasing population, strengthened communities, rising living standards, and an improving environment."

Figure 11 The peripheral areas in Hungary

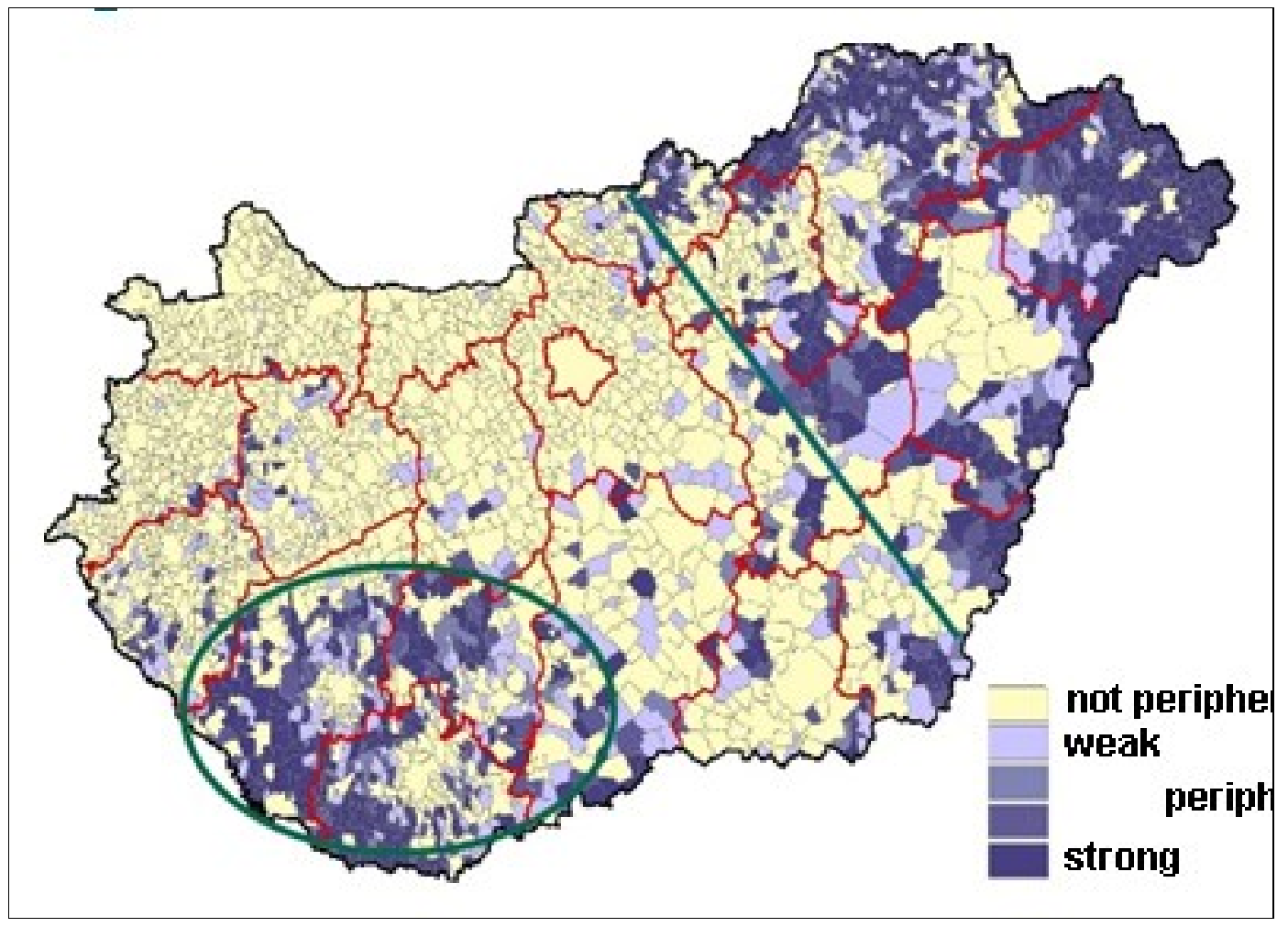

Source: Pénzes, 2014.

On the other hand, Hungary's urban development issues have been gaining increasing attention recently, as since the democratic transition in 1989-1990, different development directions were assigned to major cities in short cycles. It can be concluded that the directions and institutional frameworks of regional policies are in a constant change (Rechnitzer, Berkes, $\&$ Filep 2019). The initiative introduced in the followings (,Special Economic Zones ${ }^{\natural}$ ) is a relevant example of such a new direction and the connected institutional and regulatory framework.

The OFTK also introduced the future spatial structure that formed the basis of the Creative Region development programme. The spatial structure vision forms the so-called functional areas where specific zones of national importance could be developed for economic, social and/or environmental functions/tasks (Figure 12). 
The OFTK also identifies the territorial strategy tasks for medium and long term. The medium-term territorial strategy tasks are:

- addressing the issues of regions lagging behind, rural areas, internal and external peripheries, employment and social issues

- improving the accessibility of the border areas and strengthening their cross-border relations.

- The territorial strategy tasks laying the bases of long-term development are:

- decisive macro-regional and space organising role of Hungary

- leading role of Budapest in the macro-region

- urban network and urban policy, cities ensuring modern and quality life

- comprehensive development of cities and urban areas based on urban network cooperation

- renewal of our rural areas on economic and cultural bases, and reform of the town-country relations

- development of the talent support networks in the countryside areas.

Figure 12 Functional territories in Hungary

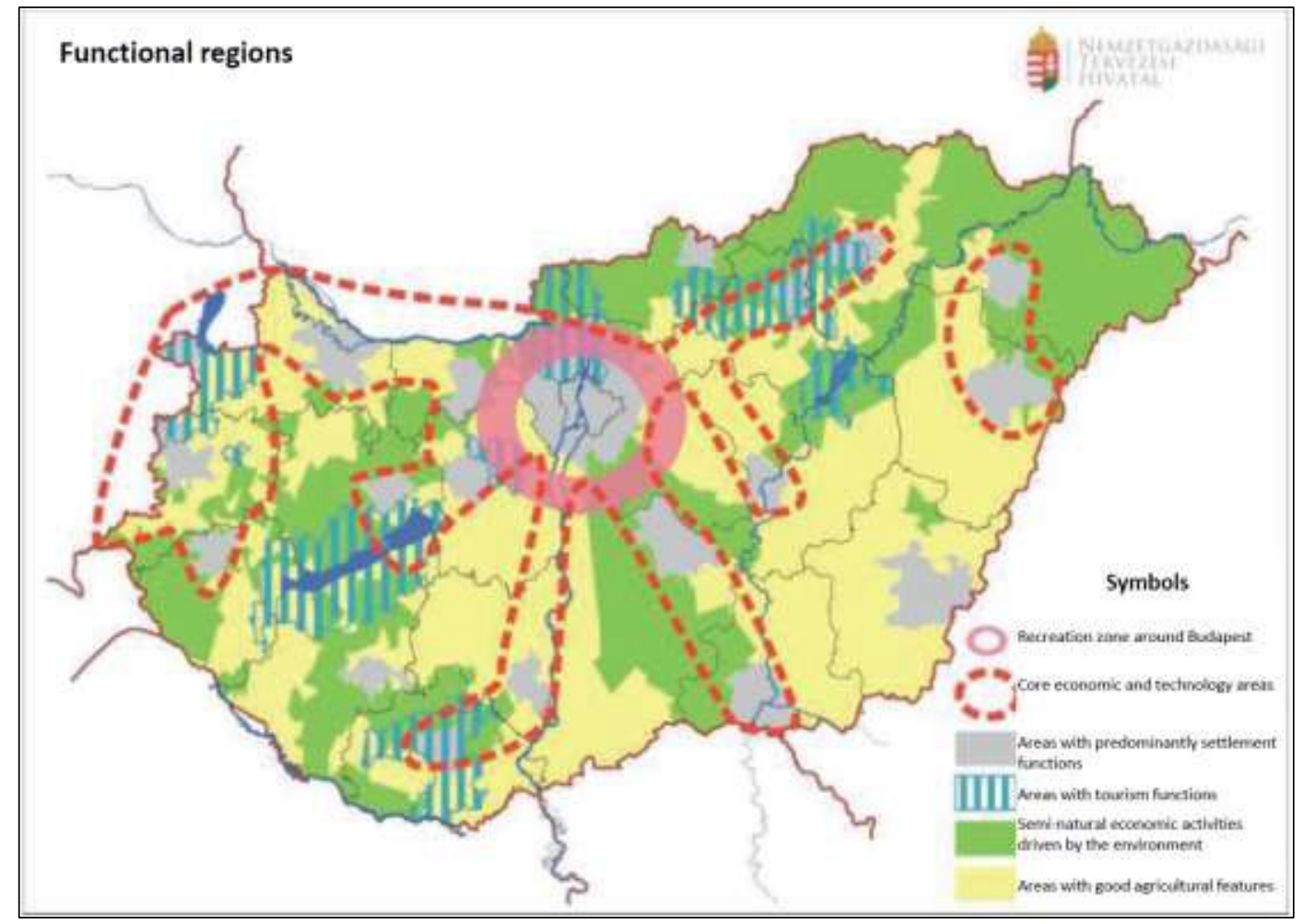

Source: National Development and Territorial Development Concept (OFTK), 2014 
Under sub-section 3.1.7.2, the OFTK also described the Development of special economic zones, as a necessary action to be taken. In the OFTK concept, the necessity of new aspects, such as investment stimulating spatial structure (especially the establishment of attractive locational conditions) are also specified, additionally to the reduction of territorial imbalances and inequalities in social and economic development.

"The whole national economy cannot be competitive if economic activity is almost "paralysed" in disadvantaged regions, which represent a considerable portion of the territory of the country. Apart from support policy, other economic incentives are also required for a territorially more balanced development of the economy. In order to facilitate economic development in the whole country, those growth and cohesion regions need to be identified where relevant territorial and economic development can be achieved with the help of targeted and integrated regional interventions. The former could be regions that already function as dynamic zones of the economy in the Hungarian structure of agglomeration with their outstanding potential sites, actual and potential investors and enterprises, while the latter category includes regions that face severe employment problems and may be (re)connected to the economic circulation of the country only with a complex development policy approach." (OFTK, 2014, p. 164).

According to the document, a special economic zone could serve as a tool of territorially selective economy stimulation, because it is a production and service providing territorial unit where the established enterprises are eligible for preferences under various conditions in order to boost economic developments in the region, for example through providing an enterprise friendly environment in line with the local specificities and available resources, to encourage investments and to enhance employment options. Additionally, it specifies cities as the urban territories of the external ring and possible counter-poles, or development poles in the countryside to be prioritized through focused investments. Under sub-section 3.1.4.6, city territories of (potential) national significance are listed, and this category includes Miskolc, Debrecen, Szeged, Pécs and Győr, as well as Székesfehérvár due to its economic power and historical role, and the catchment areas of these cities. "These cities can constitute a partly independent territorial level next to / below the capital, thus decreasing the Budapest-centred nature of the country."

Very specific examples are the relocation of national public authorities (ministries) to cities outside the capital, as shown by the case of Debrecen, among others.

These cities can provide the necessary critical mass where special cultural and economic niche needs may arise and can be satisfied over a long period of time, and their task is to channel 
and radiate innovative, technological, economic and cultural development towards their own territories in the wider sense (across several counties) and towards other cities. Additionally, the higher education and health care functions of these cities are also important, and as potential alternative centres of intellectual life outside the capital, the number of innovation scenes can be increased also, so the social elite does not depend on a single centre, thus can exhibit higher and more stable performance.

This intention could be observed also in the next part, through the presented case study, where the evolution process of these newly established economic zones in Hungary is presented. One of the cities included in the case study is Miskolc, a typical example of a Central and Eastern European city that has experienced through its history all global tendencies and major shocks starting from an oppidum, through the privileged free royal city status to municipal law rights, prioritized beneficiary of socialist industrialisation and soon after one of the main industrial crisis zones of the county to depression, pathfinding, slow recovery and repositioning in our days (Józsa, 2020).

The process of the case study began with the establishment of the so-called Creative Region, with the subtitle: Development without Borders in Northeast Hungary National, Economic and Cultural Zone. The aim of the „Creative Region - Development without borders” program is to create a single economic, educational, and cultural zone of Northeast Hungary (the counties of Borsod-Abaúj-Zemplén, Hajdú-Bihar, Jász-Nagykun-Szolnok and Szabolcs-Szatmár-Bereg) and of the cross-border areas. Here, the cross-border linkages can be observed, as identified also in the OFTK, and as a theoretical-policy level basis. Thematic working groups were formed in the fields of social innovation, infrastructure, competitiveness, the development of county seats and the involvement of the cross-border areas concerned. The Debrecen-MiskolcNyíregyháza network and the cross-border relations of the three cities are clearly the bases of strategic economic development. In order to establish an ideal investment-friendly environment it is indispensable to create (1) special development zones that offer attractive investment environment and the conditions of further growth potential together with (2) the availability of appropriate infrastructural, institutional and service background.

Here Miskolc and Debrecen can be both identified, as cities listed in the OFTK, as potential counter-poles to the capital and at the same time, cities of (potential) national significance. The Creative Region Development Zone is also connected to sub-national (regional/local) level policy documents, as follows: Borsod-Abaúj-Zemplén County Mid-term Economic Programme 2020-2024: The Creative Region Development Zone is also included in the mid-term economic programme of Borsod-Abaúj-Zemplén County. Based on governmental request, Bora 94 
Nonprofit Ltd. participates in the preparation of the work of the Coordination Forum ${ }^{2}$, and in case of further governmental decisions, in strategic programming and implementation. Debrecen 2030 program: 'Debrecen 2030' (We are together, Debrecen!') is the urban and economic development program of Debrecen City, with the aim to develop the county capital to a business-, innovation-, transport-, educational-, cultural- and health centre with a crossborder impact.

In Figure 13, the main milestones of the creation process of the newly established development zones are identified, focusing on the Creative Region initiative.

Figure 13 Milestones of the Creative Region Initiative

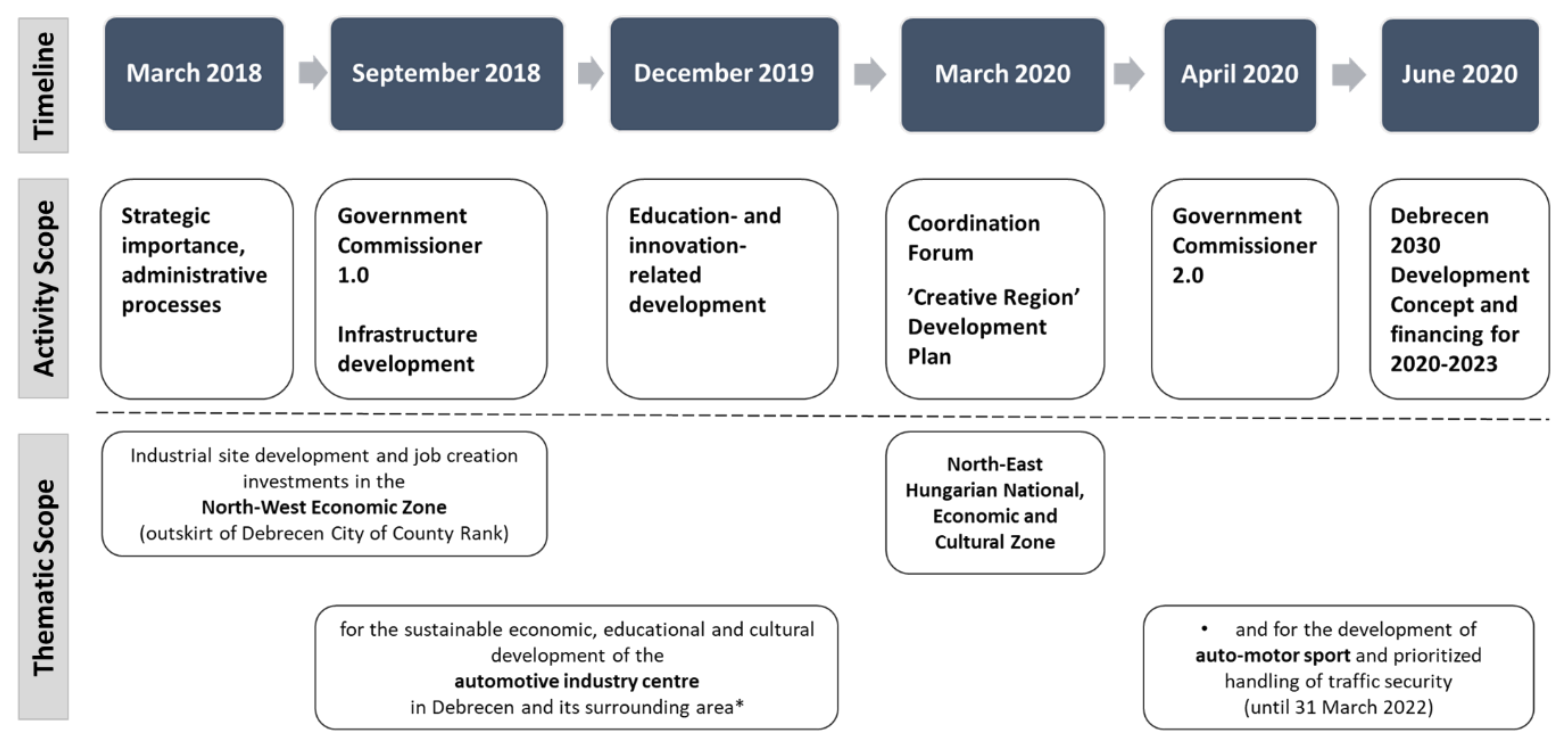

Source: own editing based on public information, 2021.

The process started in March 2018, when in connection to the launching of the BMW investment in Debrecen, the industrial site development and job creation investments in the North-West Economic Zone have received the label "issue of strategic importance for the national economy". This was an important yet relatively formal decision, but after 6 months, the nomination of the responsible government commissioner and the decision on launching the infrastructure development were already direct steps towards the operationalisation of the

\footnotetext{
${ }^{2}$ In March 2020, the mayors of the concerned cities (Miskolc: Pál Veres, Debrecen: László Papp, Nyíregyháza: Menyhért Jászai, Szolnok: Ferenc Szalay) agreed on a workshop (moderated by László Palkovics) on the common goals of increased attractiveness for citizens and competitiveness for businesses, together with infrastructural, economic, and cultural development. The mayors emphasized that they plan to implement synergetic and cross-border development projects in the next EU programming period (2021-2027). Thematic working groups have been established in the framework of the Coordination Forum, as follows: (1) social innovation, (2) infrastructure, (3) competitiveness, (4) development of the cities of county rank, (5) involvement of the cross-border areas
} 
investment decision and the connected bilateral agreement between the investor and the host country. A full year passed until the next governmental decision, the education- and innovationrelated development in connection to the automotive industry centre in Debrecen, which action is fully in line with the re-positioning and strengthening of the role of "soft" factors in the corporate embedding process observed from about 2010. At that time, the thematic scope of the decision was the "automotive industry centre in Debrecen", a new industry sector in a traditionally agricultural area (similarly to the case of Kecskemét and Mercedes-Benz). The 'Creative Region' title appeared only in 2020, when a Coordination Forum was also established and both the thematic and the geographical scope of the initiative were significantly widened. When examining the list of the forum members on the other hand, it can be concluded that no local/county level representative is included, but the highest-level representatives of the sectoral ministries (Figure 14). On the same day, the decision about the development plan of the initiative was also launched, so the decision-making (institutional) and the strategic programming background have both been generated. Soon after, the focus has been shifted back to the City of Debrecen, with some funding also: the allocation of state aids for the implementation of the short-term activities in the approved Development Concept and the necessary preparations for the medium-term actions. No other development program of the other cities of the Creative Region has been accepted outside the Development Concept of Debrecen 2030, while the initiative (in 2021) includes five counties in North-East Hungary, such as Hajdú-Bihar, Borsod-Abaúj-Zemplén, Szabolcs-Szatmár-Bereg, Jász-NagykunSzolnok and Heves (while in July 2020 only the mayors of 4 cities of county rank have signed the Cooperation Agreement, Debrecen, Miskolc, Nyíregyháza and Szolnok). Thus, the geographical scope of the initiative seems to be changing from year to year... Finally, in September 2020, the Hungarian Government launched the establishment of four economic development zones in order to enhance coordinated and harmonised territorial developments led by government commissioners also, but no specific activities or development programmes of these newly established zones have been revealed so far. 
Table 1 Policy Actions in connection to Creative Region National, Economic \& Cultural Zone

\begin{tabular}{|c|c|c|}
\hline $2018 / 03 / 26$ & 58/2018. (III. 26.) & $\begin{array}{l}\text { Government Decree about the declaration of administrative official } \\
\text { procedures in connection to the industrial site development and job } \\
\text { creation investments in the North-West Economic Zone (outskirt of } \\
\text { Debrecen City of County Rank) as matter of strategic importance for the } \\
\text { national economy }\end{array}$ \\
\hline $2018 / 09 / 25$ & 1464/2018. (IX. 25.) & $\begin{array}{l}\text { Government Decree about infrastructure development in connection to } \\
\text { the formation of North-West Economic Zone in Debrecen }\end{array}$ \\
\hline $2018 / 09 / 25$ & 1465/2018. (IX. 25.) & $\begin{array}{l}\text { Government Decree about the nomination and tasks of a Government } \\
\text { Commissioner for the sustainable economic, educational and cultural } \\
\text { development of the automotive industry centre in Debrecen and its } \\
\text { surrounding area }\end{array}$ \\
\hline $2019 / 12 / 05$ & 1680/2019. (XII. 05.) & $\begin{array}{l}\text { Government Decree about education- and innovation-related } \\
\text { development in connection to the automotive industry centre in } \\
\text { Debrecen }\end{array}$ \\
\hline $2020 / 03 / 05$ & 1072/2020. (III. 5.) & $\begin{array}{l}\text { Government Decree about the Coordination Forum of the North-East } \\
\text { Hungarian National, Economic and Cultural Zone } \\
\text {...Chair: the Government Commissioner for the sustainable economic, } \\
\text { educational and cultural development of the automotive industry centre } \\
\text { in Debrecen and its surrounding area } \\
\ldots \text { Participates in the work of the Forum as member: a) general deputy } \\
\text { of the Prime Minister, (Zsolt Semjén) b) Minister of Interior, (Sándor } \\
\text { Pintér) c) Minister of Foreign Affairs and Trade, (Péter Szijjártó) d) } \\
\text { Minister of Agriculture, (Dr. István Nagy) e) Minister of Finance, } \\
\text { (Mihály Varga) f) Minister of Human Capacities, (Dr. Miklós Kásler) g) } \\
\text { Minister of Prime Minister's Office. (Gergely Gulyás) }\end{array}$ \\
\hline $2020 / 03 / 05$ & 1073/2020. (III. 5.) & $\begin{array}{l}\text { Government Decree about the development plan of the 'Creative } \\
\text { Region' - Development without Borders in Northeast Hungary National, } \\
\text { Economic and Cultural Zone } \\
\ldots \text { the complex development of the zone should be prioritised during the } \\
\text { strategic planning of the Operational Programmes for 2021-2027, and } \\
\text { specific policy measures should be elaborated for this purpose, ... } \\
\ldots \text { umbrella projects should be developed based on individual } \\
\text { government decision, as: } \\
\text { a) Complex territorial programme for reducing inequalities } \\
\text { b) Complex territorial infrastructure development programme } \\
\text { c) Complex development programme for competitiveness and } \\
\text { employment generation } \\
\text { d) Complex development programme for } 2030 \text { about the cross-border } \\
\text { relations and cities of county rank of the economic zone }\end{array}$ \\
\hline $2020 / 04 / 03$ & 1137/2020. (IV. 3.) & $\begin{array}{l}\text { Government decree about the nomination and tasks of a Government } \\
\text { Commissioner for the sustainable economic, educational and cultural } \\
\text { development of the automotive industry centre in Debrecen and its } \\
\text { surrounding area, and for the development of auto-motor sport and } \\
\text { prioritized handling of traffic security (until } 31 \text { March 2022) }\end{array}$ \\
\hline $2020 / 06 / 10$ & 1292/2020. (VI. 10.) & $\begin{array}{l}\text { Government Decree about ensuring the financial support in the period } \\
2020-2023 \text { for the implementation of the Development Concept of } \\
\text { Debrecen } 2030 \\
\ldots \text { allocation of HUF } 29124200000 \text { for the elaboration and } \\
\text { implementation of development projects in several sectors until } 2023 \ldots \\
\ldots \text { the Minister for Innovation and Technology should make the } \\
\text { necessary measures to elaborate the proposal for the government about } \\
\text { the development projects in the next } 4 \text { years (2024-2027) programming } \\
\text { period }\end{array}$ \\
\hline
\end{tabular}

Source: own edition. 


\section{CONCLUSION}

Economy is one of (if not the) most important forces shaping space. Administrative borders and planning-statistical territorial units (national level, or EU level NUTS or LAU classifications) are rarely considered by economic actors, even if we refer to recruitment areas, logistic or other service centres for example.

The creation of Budapest Region and Pest (County) Region in 2020 on NUTS2 level can be seen as an interesting development policy experiment: how economic actors will react on the new possibilities raised by the birth of a new Convergence region and how they can exploit the better availability of EU Structural and Investment Funds. The changes happened so quickly that even the administrative background, reconciliation methods and forums have not been adapted and established yet. Though the former Central Hungary Region remained a functional Metropolitan Region, with many internal and international linkages, the internal structural problems and development inequalities have not disappeared with the split of the former NUTS2 region. It is quite clear that they can be addressed with a holistic approach and targeted development measures. The need for balanced growth and the economic catching up of disadvantaged regions is not only the problem of the Metropolitan space, but it is the longlasting task of all national development policy documents.

Though the notion and necessity of economic zones has been outlined formerly in the main policy-level document of Hungary (OFTK, 2014), the circumstances and method of their establishment both raise basic questions on transparency, rationale, timeliness, approach (topdown vs bottom-up), synergies and subsidiarity - without being extensive. When examining the current strategic programming processes, it can be declared that at the EU level the number of objectives has been significantly decreased with a stronger focus on a few strategic aims, while in Hungary, at a Member State level, the number of objectives has been significantly increased, with a widened thematic focus. When comparing 2014-2020 with 2021-2027, an evolution (and not a revolution) can be experienced in the programming documents, that can ensure a continuity - a possibly positive feature in our challenging era full of disruptive processes and global level vis majors. On the other hand, territoriality and regionalism (even regionalisation) are further retarded by the fact that Hungary still does not plan to use either the Integrated Territorial Initiatives (ITI) or the Community-Led Local Development (CLLD) opportunities, among others. Thus, it is strongly questionable if the creation (and operation?) of the new special economic zones could have a significant and measurable impact on the reduction of territorial inequalities, mentioning only one aspect... 
The case of surface waters is an example of how a geographical phenomenon can be addressed by both sectoral and territorial policies, and the existence of a link between them is not predetermined (territorial dimensions can be found in the former, while sectoral characteristics in the latter). The phenomenon of surface waters is a well-managed field in the EU through environmental policy, however, it is currently less emphasized due to the centrality of atmosphere in the Green Deal. The surface areas are very important in Hungary's environmental system, social and economic life, and policies. From a sectoral point of view, integrated water management is emphasized, in which quantity, quality issues and ecosystems appear regularly. Here, the territorial dimension brings forth river basin districts where international cooperation, crossing national and regional borders appear, and local communities are important, where local water management is emphasized. From the point of view of territorial policy, although its weight and detail vary from document to document, the main sectoral objectives are present and major surface waters have become an important element of national development goals, within which special attention is paid to flood management, mitigation of droughts related to climate change. However, the documents examined show a mixed picture about the coherence of relevant policies: interconnection appears in relation to national level plan(s), but at the regional level, there are separate planning paths for different territorial units (in addition to mutual commenting on each other's documents).

The current European environmental policy, reinforced with the Water Framework Directive, favours Hungary. Beyond that, although water issues are represented in the Green Deal, the atmosphere is more critical, as for example the greenhouse effects receive much more attention than water management. However, the effects of climate change are water-related, so it is Hungary's strong interest to emphasize this and further strengthen the role of the country's surface waters in EU policies.

\section{Acknowledgement}

The research of Viktória Józsa was funded by the Hungarian National Research, Development and Innovation Office - NKFIH grant 134903 (Geopolitical Processes and Imaginaries in Central Europe: States, Borders, Integration and Regional Development).

\section{REFERENCES}

Bachtler, M., \& Wostner, Z. (2019). Towards Cohesion Policy 4.0. Regional Studies Impact Books. OECD, RSA.

Berkes, J. (2020). The Economic Structure and Performance of the Catchment Area of the Hungarian Regional Centers. Deturope, 12 (3), 58-81.

BM (Ministry of Interior, Hungary) (2017). Kvassay Jenö Plan. https://www.vizugy.hu /index.php?module=vizstrat\&programelemid=143 (Downloaded: May 20, 2021). 
Crescenzi, R., Fratesi, U., \& Monastiriotis, V. (2020). Back to the member states? Cohesion Policy and the national Challenges to the European Union. Regional Studies, 54(1), 5-9.

C(2020) 6769 Decision of the European Commission on 7 October 2020) about the extension of the Hungarian regional state aid map until 31 December 2021.

EC (2018): Regional Development and Cohesion Policy 2021-2027. https://ec.europa.eu/ regional_policy/en/newsroom/news/2018/06/06-08-2018-regional-development-andcohesion-policy-2021-2027 (Downloaded: July 10, 2021)

EC (2020a). New Cohesion Policy. https://ec.europa.eu/regional_policy/en/2021_2027/\#1 (downloaded: October 10, 2021).

EC (2020b): Priorities for 2021-2027. https://ec.europa.eu/regional_policy/hu/policy/how /priorities (Downloaded: October 5, 2021).

EC (2000c): EU Water Framework Directive. https://eur-lex.europa.eu/legalcontent /EN/TXT/HTML/?uri=CELEX:32000L0060\&from=EN (Downloaded: May 15, 2021).

EC (2021a). Environment. https://ec.europa.eu/environment/index_en (Downloaded: May 21, 2021)

EC (2021b). Macroregional Strategies; European Union. https://ec.europa.eu/regional policy/en/policy/cooperation/macro-regional-strategies (Downloaded: May 20, 2021)

EC (2021c). A European Green Deal. https://ec.europa.eu/info/strategy/priorities-20192024/european-green-deal_en (Downloaded: May 25, 2021)

Fiaschi, D., Lavezzi, A. M., \& Parenti, A. (2018). Does EU cohesion policy work? Theory and evidence. Journal of Regional Science, 58(2), 386-423.

Gál, Z., Lux, G., \& Illés, I. (2013). (Eds.) Danube Region: Analysis and Long-Term Development Trends of the Macro-Region. Pécs, Institute of Regional Studies, Centre for Economic and Regional Studies, Hungarian Academy of Sciences.

Józsa, V. (2020). Miskolc - A Central and Eastern European City in the Crossroads. Deturope, 12(3), 82-107.

Megyesi, Z., \& Péti, M. (2019). A Comparative Analysis of the Socio-Economic Development of Romanian Cities and Towns Inhabited by Ethnic Hungarians. Deturope, 11(3), 205228.

MIT (Ministry for Innovation and Technology) (2020). Evaluation of Integrated Territorial Implementation. https://www.palyazat.gov.hu/az-integrlt-terleti-vgrehajts-rtkelse

Nemes Nagy, J. \& Tagai, G. (2009). Területi egyenlőtlenségek, térszerkezeti determinációk. Területi Statisztika, 12 (49), 152-169.

OFTK (2014). National Development 2030 - National Development and Territorial Development Concept. Hungarian Official Journal Volume 2014. Issue No. 1.: Parliament Resolution No. 1/2014. (I. 3.) OGY National Development 2030 - National Development and Territorial Development Concept.

Nyikos, Gy. \& Soós, G. (2020). The Hungarian Experience of Using Cohesion Policy Funds and Prospects. In Musiałkowska, I., Idczak P. \& Potluka, O. (Ed.), Successes \& Failures in EU Cohesion Policy: An Introduction to EU cohesion policy in Eastern, Central, and Southern Europe. De Gruyter Open Poland. Doi:10.1515/9788395720451-007

OGY (1996). The Act XXI of 1996 on Regional Development and Regional Planning (IV.5.) https://net.jogtar.hu/jogszabaly?docid=99600021.tv

PA (2014). Partnership Agreement of Hungary. https:/ec.europa.eu/info/publications/ partnership-agreement-hungary-2014-20_hu (Downloaded: July 12, 2021)

PA (2021). Partnership Agreement of Hungary. (May 12. 2021.) https://www.palyazat.gov.hu/ partnersegi-megallapodas (Downloaded: July 12, 2021). 
Parliament Resolution (2020a). A Kormány 1566/2020. (IX. 4.) Korm. határozata az Északkelet-magyarországi Gazdaságfejlesztési Zóna komplex fejlesztéséért felelös kormánybiztos kinevezéséröl és feladatairól; Magyar Közlöny, 201. (2020. szeptember 4.) https://magyarkozlony.hu (Downloaded: September 14, 2021).

Parliament Resolution (2020b). A Kormány 1567/2020. (IX. 4.) Korm. határozata az Északnyugat-magyarországi Gazdaságfejlesztési Zóna komplex fejlesztéséért felelös kormánybiztos kinevezéséről és feladatairól; Magyar Közlöny, 201. (2020. szeptember 4.) https://magyarkozlony.hu (Downloaded: September 14, 2021)

Parliament Resolution (2020c). A Kormány 1568/2020. (IX. 4.) Korm. határozata a Dél-alföldi Gazdaságfejlesztési Zóna komplex fejlesztéséért felelös kormánybiztos kinevezéséröl és feladatairól; Magyar Közlöny, 201. (2020. szeptember 4.); https://magyarkozlony.hu (Downloaded: September 14, 2021)

Parliament Resolution (2020d). A Kormány 1569/2020. (IX. 4.) Korm. határozata a Déldunántúli Gazdaságfejlesztési Zóna komplex fejlesztéséért felelös kormánybiztos kinevezéséröl és feladatairól; Magyar Közlöny, 201. (2020. szeptember 4.); https://magyarkozlony.hu (Downloaded: September 14, 2021)

Pest County Development Concept 2030, revised version, 2021. http://www.pestmegye.hu/ dokumentumok-teruletfejlesztes/4399-pest-megyei-teruletfejlesztesi-koncepcio-2030felulvizsgalt-valtozat (Downloaded: November 10, 2021).

Pénzes, J. (2014). Periférikus térségek lehatárolása - dilemmák és lehetöségek. Debrecen: Didakt Kft.

Rácz, Sz. (2019). Development Processes of Regional Centres in Central and Southeast Europe - From State Socialism to Dependent Market Economies. Deturope, 11(2), 92-100.

Rechnitzer, J., Berkes, J. \& Filep, J. (2019). The most important city development initiatives of Hungary. Regional Statistics, 9(2), 20-44. Doi:10.15196/RS090204

Revised Regional Aid Guidelines (RAG) accepted on 16 September 2021 by the European Commission, including the Hungarian regional aid map for 2022-2027.

Rodríguez-Pose, A., \& Dijkstra, L. (2020). Does Cohesion Policy reduce EU discontent and Euroscepticism? Working Paper, Research and indicators produced by the DirectorateGeneral for Regional and Urban Policy, WP 04/2020, p28.

Rodríguez-Pose, A., \& Dijkstra, L. (2021). Does Cohesion Policy reduce EU discontent and Euroscepticism? Regional Studies, 55(1), 354-369.

Rodríguez-Pose, A., \& Novak, K. (2013). Learning processes and economic returns in European Cohesion Policy, Investigaciones Regionales, 25, 7-26.

Szabó, P. (2017). Makroregionális szemlélet az Európai Unió regionális politikai dokumentumaiban. In Szónokyné Ancsin, G. (Ed.), Magyarok a Kárpát-medencében 2. (pp. 485-497). Szeged: Egyesület Közép-Európa Kutatására.

Szilágyi, J. (2019). Systematization and some current issues of water law and water regulation in the framework of the European Union. Journal of Agricultural and Environmental Law, 14 (26), 255-275.

UN (2015). 17 Sustainable Development Goals. https://www.un.org/sustainable development/ water-and-sanitation (Downloaded: May 20, 2021). 